\title{
Oxygen Isotope Systematics in an Evolving Geothermal System: Coso Hot Springs, California
}

Thomas M. Etzel ${ }^{1,2}$, John R. Bowman ${ }^{1}$, Joseph N. Moore ${ }^{2}$, John W. Valley ${ }^{3}$, Michael J. Spicuzza $^{3}$, Jesse M. McCulloch ${ }^{4}$

${ }^{1}$ Dept. of Geology and Geophysics, University of Utah, Salt Lake City, UT 84112; ${ }^{2}$ Energy \& Geoscience, Institute, University of Utah, Salt Lake City, UT $84108 ;{ }^{3}$ Dept. Of Geoscience, University of Wisconsin, Madison, WI 54706; ${ }^{4}$ Terra-Gen Operating Company, Little Lake, CA, USA

\section{$\underline{\text { ABSTRACT }}$}

Oxygen isotope and clay mineralogy studies have been made on whole rock samples and feldspar separates from three wells along the high temperature West Flank of the Coso geothermal system, California. The reservoir rocks have experienced variable ${ }^{18} \mathrm{O} /{ }^{16} \mathrm{O}$ depletion, with $\delta^{18} \mathrm{O}$ values ranging from primary values of $+7.5 \%$ down to $-4.6 \%$. Spatial patterns of clay mineral distributions in the three wells are not closely correlated with the distributions expected from measured, pre-production temperature profiles, but do correlate with spatial patterns of ${ }^{18} \mathrm{O} /{ }^{16} \mathrm{O}$ depletion, indicating that the stability of clay minerals in the three wells is a function of fluid-rock interaction in addition to temperature. Detailed $\delta^{18} \mathrm{O}$ measurements in the three wells identify a limited number of localized intervals of extensive ${ }^{18} \mathrm{O} /{ }^{16} \mathrm{O}$ depletion. These intervals document localized zones of higher permeability in the geothermal system that have experienced significant fluid infiltration, water-rock interaction and oxygen isotopic exchange with the geothermal fluids. The local zones of maximum ${ }^{18} \mathrm{O} /{ }^{16} \mathrm{O}$ depletion in each well correspond closely with current hot water production zones. Most feldspar separates have measured $\delta^{18} \mathrm{O}$ values too high to have completely attained oxygen isotope exchange equilibrium with the reservoir fluid at pre-production temperatures. In general, the lower the $\delta^{18} \mathrm{O}$ value of the feldspar, the closer the feldspar approaches exchange equilibrium with the geothermal fluid. This correlation suggests that fracture-induced increases in permeability increase both fluid 
30 infiltration and the surface area of the host rock exposed to geothermal fluid, promoting fluid-

31 rock interaction and oxygen isotope exchange. The two most ${ }^{18} \mathrm{O} /{ }^{16} \mathrm{O}$-depleted feldspar samples

32 have $\delta^{18} \mathrm{O}$ values too low to be in exchange equilibrium with the pre-production reservoir fluid at

33 pre-production temperatures. These discrepancies suggest that the reservoir fluid in the West

34 Flank of the Coso geothermal system was hotter and/or had a lower $\delta^{18} \mathrm{O}$ value (due to fluid-rock

35 interaction at higher permeability) in the past. of the Sierra Nevada Mountains at the western boundary of the Basin and Range Province (fig.

41 1). Coso Hot Springs is a world-class geothermal field; it is the third largest producing

42 geothermal field in the United States, among the hottest, with an installed power capacity of 273

43 MWe and temperatures as high as $350^{\circ} \mathrm{C}$ at depths as shallow as $\sim 1 \mathrm{~km}$. It is also one of the most

44 extensively drilled geothermal systems, with many of the more than 150 wells reaching depths of $45 \quad 2-3 \mathrm{~km}$. reservoir rocks, which consist dominantly of metamorphosed Mesozoic diorite and younger 48 granodiorite and granite. Although epidote, chlorite, illite, quartz, and calcite, which are typical

49 of high-temperature geothermal systems worldwide (Henley and Ellis, 1985), are widespread at

50 Coso Hot Springs, these minerals show no clear correlation with temperature (Bishop and Bird,

51 1987; Lutz et al., 1996; Lutz and Moore, 1997; Kovac et al., 2004; Kovac et al., 2005). In

52 contrast, minerals typical of moderate temperature environments, such as wairakite and prehnite, 53 are rarely observed in the reservoir rocks. 


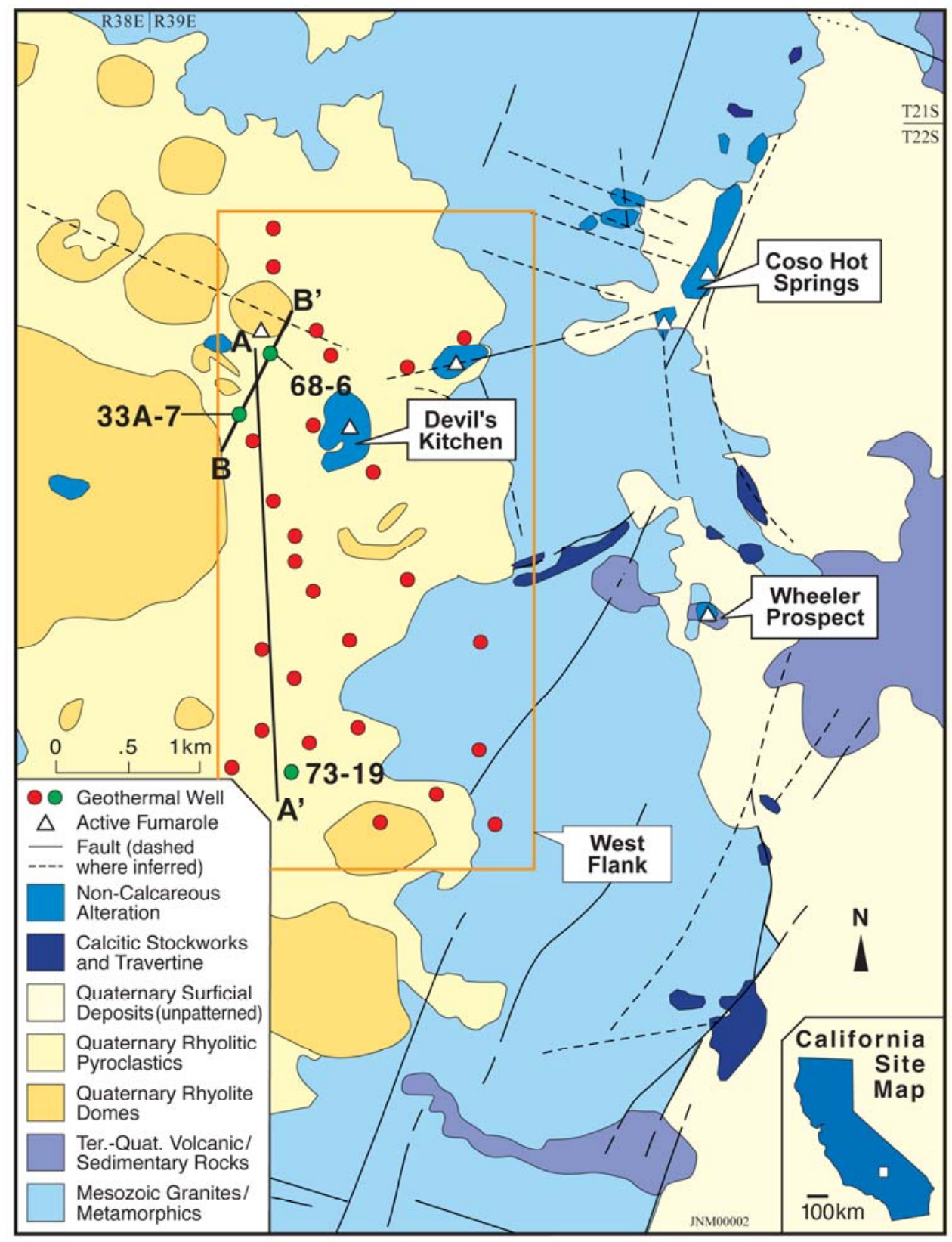

55 Figure 1: A simplified geologic map of the Coso Geothermal system (modified from Hulen,

56 1978) located on the Naval Air Weapons Station, China Lake, California. The West Flank of the

57 system is defined by a North-South trending thermal high (Terra-Gen, unpublished data); it is the

58 focus of this study. Line A-A' along this thermal high is the transect for a number of cross

59 sections used in this study. Line B-B' is a cross section line through wells 68-6 and 33A-7.

60 Locations of wells in the West Flank used in this study are marked by red and green circles; the

61 green circles indicate wells examined in detail for this study while the red circles indicate wells

62 examined in previous studies. Only the wells in the West Flank with oxygen isotope data for host

63 rocks are shown; none are shown for other areas. 
Oxygen isotopes provide an alternative means of mapping subtle changes in the extent

66 and distribution of fluid-rock interactions that are independent of the bulk mineralogy. Active

67 geothermal systems provide unique opportunities to examine the interaction between geothermal

68 fluids and host rocks. Person et al. (2006) used heat flow data and $\delta^{18} \mathrm{O}$ values of reservoir fluids

69 to constrain a regional-scale numerical model of the flow system supplying the Coso geothermal

70 system. Recently, Pope et al. (2016) measured $\delta \mathrm{D}$ and $\delta^{18} \mathrm{O}$ values of hydrothermal epidote from

71 the Krafla, Iceland geothermal system. They interpreted variations in the $\delta \mathrm{D}$ and $\delta^{18} \mathrm{O}$ values of

72 both the epidote and reservoir fluids to result from variable mixing of shallow, sub-boiling

73 groundwaters with vapor condensates derived from an underlying two-phase reservoir, also

74 derived from local meteoric waters. Here we report on oxygen isotope analyses of whole-rock

75 samples from the Coso geothermal system, and detailed whole-rock and mineral analyses from

76 three producing wells. Our whole-rock results define ${ }^{18} \mathrm{O} /{ }^{16} \mathrm{O}$ depletion patterns in the

77 geothermal system distinct from those expected from regional metamorphism whereas the

$78{ }^{18} \mathrm{O} /{ }^{16} \mathrm{O}$ patterns from the three wells identify discrete intervals of maximum ${ }^{18} \mathrm{O} /{ }^{16} \mathrm{O}$ depletion

79 that correspond closely with zones of current hot water production and high permeability. These

80 discrete, higher permeability zones have experienced significant fluid infiltration, water-rock

81 interaction and oxygen isotopic exchange with the geothermal fluids. These results document a

82 correlation between the extent of oxygen isotope exchange (e.g., extent of ${ }^{18} \mathrm{O} /{ }^{16} \mathrm{O}$ depletion) and

83 fluid-rock interaction recorded in the host rocks with host rock permeability. The results of this

84 study have broader applications to fossil hydrothermal systems and Enhanced Geothermal

85 Systems developed in crystalline host rocks. 
The Coso Hot Springs geothermal system is developed in Mesozoic plutonic rocks of the

89 Sierra Nevada Batholith (Duffield et al., 1980). Diorite that was regionally metamorphosed at

90 greenschist to lower amphibolite facies conditions to orthogneiss in the late Cretaceous (Bartley

91 et al., 2007) (fig. 1) is the most common rock type. Younger intrusions consist of granodiorite

92 and granite (Duffield et al., 1980). Subsequent episodes of Cenozoic volcanism produced basalt

93 and rhyolite at 4.0-2.5 Ma and 1.1-0.044 Ma (Kurliovitch et al., 2003; Duffield et al., 1980). The

94 youngest episode is related to a silicic magma chamber emplaced between 5-20 km depth

95 (Duffield et al., 1980; Reasenberg et al., 1980; Manley and Bacon, 2000). This magma body

96 produces the heat driving the current geothermal activity (Duffield et al., 1980).

Surface expressions of geothermal activity include opaline $\left(\mathrm{SiO}_{2}\right)$ sinter and travertine

$98\left(\mathrm{CaCO}_{3}\right)$ spring deposits. ${ }^{14} \mathrm{C}$ dating of pollen in hot spring deposits has yielded ages of 11,550 to

99 8,550 years (Moore, unpublished data). The geothermal fluids (Table 1) have low salinities

$100(5,000-10,000 \mathrm{ppm}$ TDS $)$, and are $\mathrm{NaCl}$-dominated. The pre-production geothermal waters are

101 dominated by a single-phase system with minimal boiling (Fournier et al., 1980), but there is

102 some mineral alteration evidence for a natural steam cap in places (Williams and McKibben,

103 1990). Geochemical and hydrogen isotope data indicate that the system is predominately

104 recharged by meteoric fluids (Adams et al., 2000; Moore et al., 1990; Williams and McKibbin,

105 1990; unpublished results, Terra-Gen Operating Co.). The modeling results of Person et al.

106 (2006) suggest that the geothermal fluids are recharged by lateral flow of groundwaters

107 (meteoric waters) from fault systems and possibly the Sierra Nevada mountains to the west of the

108 Coso field. Their model has these groundwaters infiltrating to the top of the brittle-ductile

109 transition at 4-5 km depth (Wilson et al., 2003), becoming enriched in ${ }^{18} \mathrm{O} /{ }^{16} \mathrm{O}$ to the maximum

110 measured $\delta^{18} \mathrm{O}$ values of the geothermal reservoir fluids (-6 \%o) through fluid-rock isotopic 
111 Table 1: The composition of pre-production geothermal fluids from wells 68-6, 33A-7 and 73-19 112 (Terra-Gen, unpublished data). Chemistry in ppm by weight; $\delta^{18} \mathrm{O}$ and $\delta \mathrm{D}$ in per mil (\%) relative 113 to VSMOW.

114

\begin{tabular}{rccc}
\hline & $68-6$ & $33 \mathrm{~A}-7$ & $73-19$ \\
\hline $\mathrm{Na}$ & 748.7 & 1273.1 & 2043.9 \\
$\mathrm{~K}$ & 136.0 & 187.4 & 579.3 \\
$\mathrm{Ca}$ & 7.4 & 6.8 & 49.7 \\
$\mathrm{Li}$ & 6.5 & 10.7 & 26.9 \\
$\mathrm{Mg}$ & 0.3 & $\mathrm{~N} / \mathrm{A}$ & $\mathrm{N} / \mathrm{A}$ \\
$\mathrm{B}$ & 39.4 & 57.6 & 88.7 \\
$\mathrm{SiO}_{2}$ & 596.3 & 514.4 & 601.9 \\
$\mathrm{HCO}_{3}$ & 102.1 & 123.6 & 44.4 \\
$\mathrm{SO}_{4}$ & 30.4 & 40.1 & 15.7 \\
$\mathrm{Cl}$ & 1259.9 & 2163.0 & 3783.4 \\
$\mathrm{~F}$ & 2.6 & 2.6 & 2.3 \\
$\delta^{18} \mathrm{OW}_{\mathrm{W}}$ & $-8.46 \% 0$ & $-7.49 \%$ & $-6.04 \%$ \\
$\delta \mathrm{D}$ & $-104.1 \% \mathrm{~N} \%$ & $\mathrm{~N} / \mathrm{A}$ & $-96.0 \% 0$ \\
$\mathrm{Date}$ & $6 / 26 / 1995$ & $7 / 28 / 2009$ & $10 / 26 / 1988$ \\
\hline
\end{tabular}

116 exchange at elevated temperature, and then ascending to form the thermal plume of the Coso

117 reservoir. Northerly trending, Basin and Range faulting and local dextral strike-slip faulting 118 associated with the younger Walker Lane/Eastern California Shear Zone, guide fluid flow and

119 influence current geothermal activity (Monastero et al., 2005; Kaven et al., 2012). Additional

120 details about the geology, including hydrothermal alteration, are provided by Hulen (1978),

121 Duffield et al. (1980), Lutz et al. (1996), Adams et al. (2000), Manley and Bacon (2000), Kovac 122 et al. (2005) and Etzel (2015).

\section{Thermal Structure}

124 Borehole measurements have defined a north-south trending zone of high temperatures

125 on the West Flank of the field (fig. 1). Geochemical and thermal data suggest that the system is

126 compartmentalized with upflow zones in the northeast and southwest (Williams and McKibben,

127 1990). Figure 2 shows the thermal structure of the West Flank of the system based on pre-

128 production temperature data. Maximum measured temperatures at depth reach $350^{\circ} \mathrm{C}$. Reservoir 


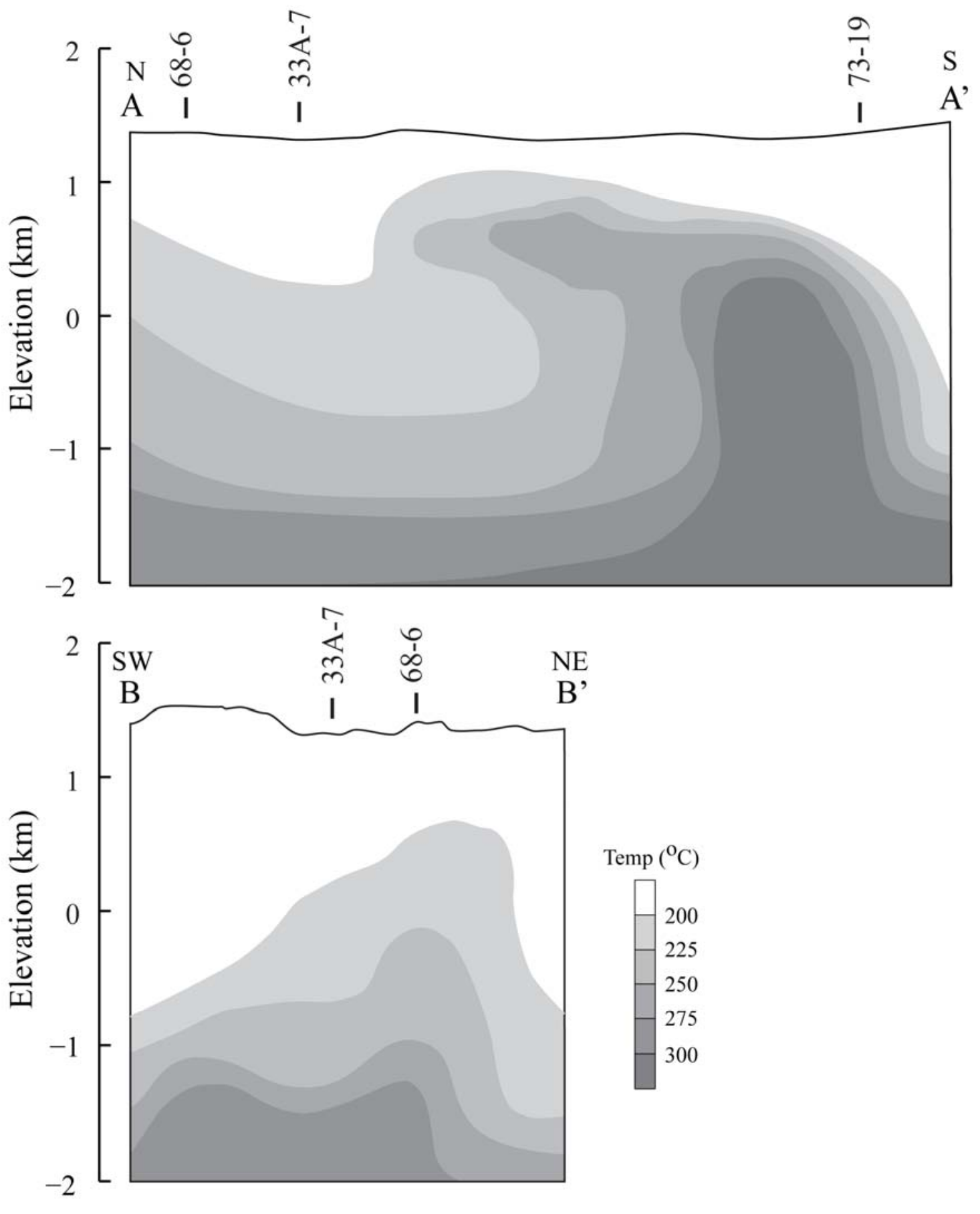

130 Figure 2: General north-south thermal structure of the West Flank along the transects A-A' and 131 B-B'. Temperature values come from down-hole measurements made prior to production. 132 
133 temperatures in the south are higher than in the north at equivalent elevations. The thermal

134 pattern defines a plume of hot water that ascends in the south and then migrates laterally

135 northward.

\section{$\underline{\text { METHODS }}$}

137 Rock cuttings were sampled at regular intervals (nominally $\sim 30-80 \mathrm{~m}$ apart) in wells 68-

138 6, 33A-7 and 73-19 for oxygen isotope, X-ray diffraction (XRD) and petrographic analyses. Thin

139 sections were examined using a petrographic microscope under transmitted light to identify

140 primary and secondary (alteration) minerals, vein mineral assemblages and their paragenesis,

141 structural features and the host rock lithology. Etzel (2015) provides a detailed presentation of

142 these results.

143 Clay mineralogy and clay mineral abundances have been determined by standard

144 techniques for preparing clay fractions $(<2 \mu \mathrm{m}$ size fraction) and standard $\mathrm{x}$-ray diffractometry

145 techniques (Lutz and Moore, 1997). The detection limit for clay minerals is 0.3 wt. \%.

146 Additional details of these techniques, clay mineralogy and of host rock lithology are reported in

147 Etzel (2015).

148 Oxygen isotopic measurements were conducted at the University of Wisconsin-Madison

149 on 91 whole rock samples and 30 feldspar separates from wells 68-6, 33A-7 and 73-19. Mineral

150 separates were made using a Frantz magnetic separator followed by hand-picking under a

151 stereoscopic microscope. The oxygen isotope analyses were done by laser-aided fluorination

152 using a lasing sample chamber outfitted with an airlock sample chamber to prevent pre-

153 fluorination of reactive rock powders (Spicuzza et al., 1998). Oxygen isotope values were

154 standardized using UWG-2 garnet standard (Valley et al., 1995) and are reported in the standard

$155 \delta^{18} \mathrm{O}$ notation, relative to VSMOW. 
RESULTS

The reservoir rocks observed in wells 68-6, 33A-7 and 73-19, the three wells studied in

159 detail (well locations shown in fig. 1) are principally diorite orthogneiss with subordinate diorite 160 and granodiorite.

161 Two episodes of overprinting on the primary (igneous) mineralogy of the reservoir rocks 162 are recognizable (Bishop and Bird, 1987; Lutz et al., 1996; Lutz and Moore, 1997; Kovac et al., 163 2005; Etzel, 2015). Regional lower amphibolite to greenschist facies metamorphism (late 164 Cretaceous) has produced plagioclase, hornblende, biotite, epidote, titanite, chlorite and illite 165 (muscovite) throughout all three wells (figs. 3, 4a, b). During subsequent geothermal activity, 166 chlorite replaced hornblende and biotite, and epidote, illite (muscovite) and other clay minerals 167 replaced plagioclase (fig. 4c-f). This geothermal activity has resulted in progressive changes in 168 temperature sensitive clay minerals with depth. Throughout the field, smectite (S) is present at 169 the shallowest depths, followed by interlayered illite/smectite (I/S) and rare chlorite/smectite, 170 and finally illite and chlorite at deeper levels. Smectite, interlayered illite-smectite and illite 171 replace plagioclase; chlorite and rare interlayered smectite/chlorite replace biotite and 172 hornblende (fig. 4c-f).

173 The deepest occurrence of smectite above trace levels defines the base of the smectite 174 zone at an elevation of about 1000 meters in wells 68-6 and 33A-7 (fig. 3). In well 73-19, 175 smectite occurs only at trace levels ( 0.3 to $1 \%)$ and occurs persistently only at elevations above $176 \sim 300 \mathrm{~m}$ (fig. 3). The deepest occurrence of interlayered illite-smectite above trace levels defines 177 the base of the I/S zone in wells $33 \mathrm{~A}-7$ and $73-19$ at elevations of -41 meters and -143 meters, 178 respectively. Interlayered illite-smectite is completely absent in well 68-6. Trace amounts of the 


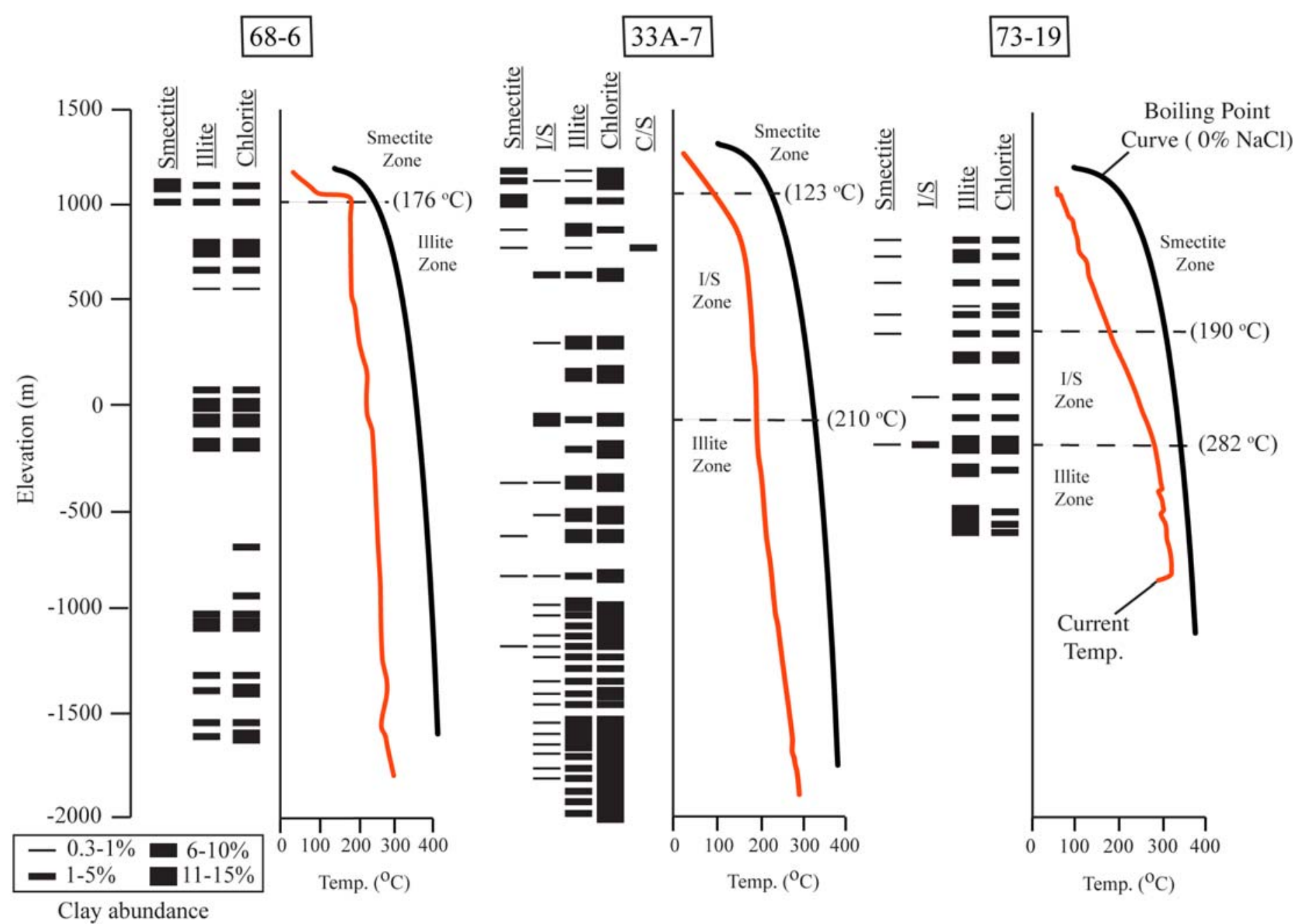

179 Figure 3: Clay mineral content and measured pre-production temperature profiles for wells $68-6,33 \mathrm{~A}-7$ and $73-19 . \mathrm{I} / \mathrm{S}=\mathrm{interlayered}$

181 illite-smectite; $\mathrm{C} / \mathrm{S}=$ interlayered chlorite-smectite. Dashed lines denote locations at which clay transitions occur; measured

182 temperatures at these locations are in parentheses. 


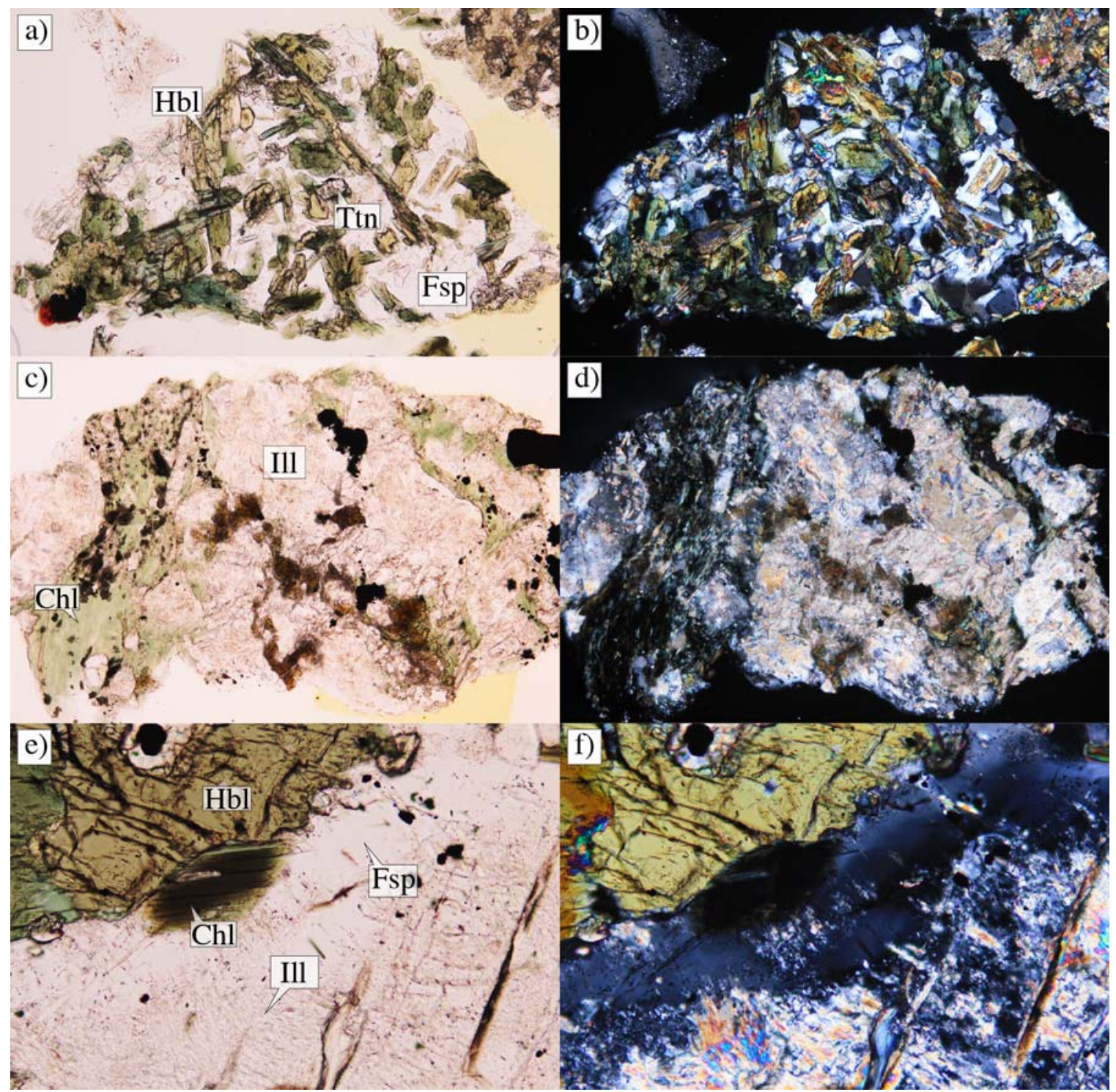
Figure 4: Photomicrographs of the lithologies and alterations observed in the Coso geothermal 186 system. Panels a) and b) show a typical unaltered meta-diorite sample with hornblende (Hbl), 187 untwined feldspar (Fsp), and rare anhedral titantite (Ttn). This sample is from 33A-7_1100. 188 Panels c) and d) show extensive geothermal-related alteration in feldspar, hornblende and biotite 189 found in 68-6_2792. Feldspar is altered to illite (Ill); hornblende and biotite are completely 190 altered to chlorite (Chl). Panels e) and f) show a feldspar partially altered to illite found in 68191 6_2941. The field of view in panels a) - d) is $1.6 \mathrm{~mm}$ and in panels e) and f) is $0.8 \mathrm{~mm}$.

193 lower temperature smectite and interlayered I/S clays exist within the illite zone in 33A-7 (fig.

194 3). The transitions from smectite to interlayered illite/smectite to illite typically occur at

196 temperatures of $\sim 180^{\circ} \mathrm{C}$ and $225^{\circ} \mathrm{C}$, respectively (Steiner, 1968; Browne, 1978; Henley and Ellis, 
197 1983; Browne, 1984; Reyes, 1990). However in the three Coso wells, these transitions do not

198 always occur at or near these temperatures, based on measured pre-production temperatures (fig.

199 3). In 33A-7, the smectite to interlayered illite/smectite and illite/smectite to illite transitions

200 occur well below expected temperatures at $\sim 125^{\circ} \mathrm{C}$ and $\sim 210^{\circ} \mathrm{C}$, respectively. In well $73-19$, the

201 smectite to interlayered illite/smectite transition occurs near the expected $\mathrm{T}$ of $180^{\circ} \mathrm{C}$, but

202 interlayered illite/smectite persists to depths where temperatures reach $280^{\circ} \mathrm{C}$. In $68-6$ smectite

203 disappears near a pre-production temperature of $180^{\circ} \mathrm{C}$ (at an elevation of $\sim 1000$ meters), its

204 expected limit of thermal stability, but no interlayered illite/smectite is present below the

205 smectite. These discrepancies suggest that temperature variations alone cannot explain the

206 detailed distribution of clay minerals observed in these wells.

207 Whole Rock Oxygen Isotope Characteristics of the Coso Hot Springs Geothermal System

208 General patterns of $\delta^{18} \mathrm{O}$ variation as a function of elevation in the Coso geothermal field

209 are illustrated in figure 5. These plan maps are based on 513 whole rock $\delta^{18} \mathrm{O}$ analyses of well-

210 cuttings supplied by Terra-Gen Operating Company (Supplementary Data Table 1), plus 91

211 additional whole rock $\delta^{18} \mathrm{O}$ values measured in this study (table 2). The plan maps of $\delta^{18} \mathrm{O}$

212 variations shown in figure 5 were constructed by averaging the $\delta^{18} \mathrm{O}$ values within $480 \mathrm{~m}$

213 intervals in each well; sufficient analyses were not available deeper than $1125 \mathrm{~m}$ below sea-level

214 to construct a useful plan map. Near surface $\delta^{18} \mathrm{O}$ values (surface to $800 \mathrm{~m}$ elevation) are similar

215 with, or slightly lower than, measured $\delta^{18} \mathrm{O}$ values for primary igneous rock in the Central Sierra 
Range: Surface to 800 meters

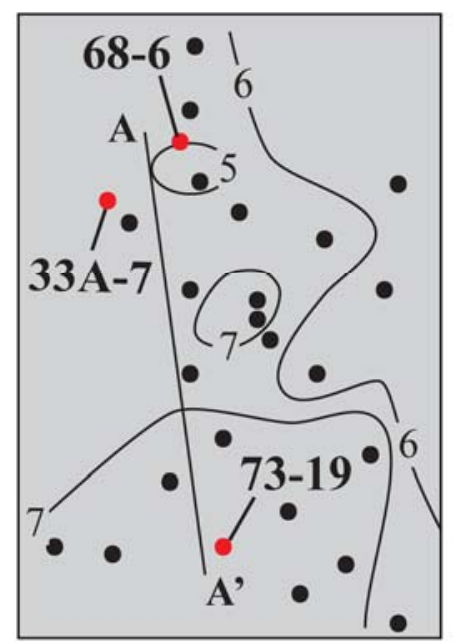

Range: 800 meters to 320 meters

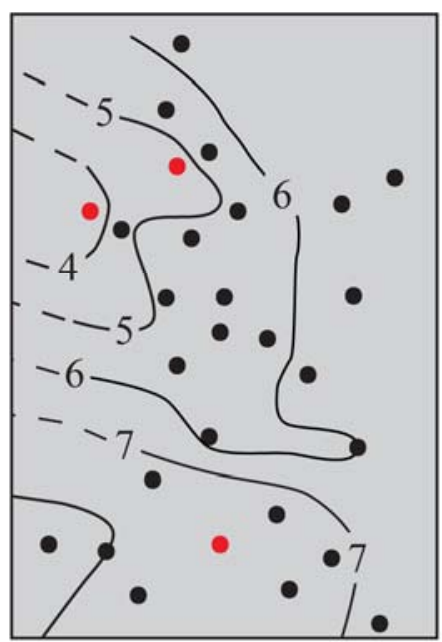

Range: 320 meters to -165 meters

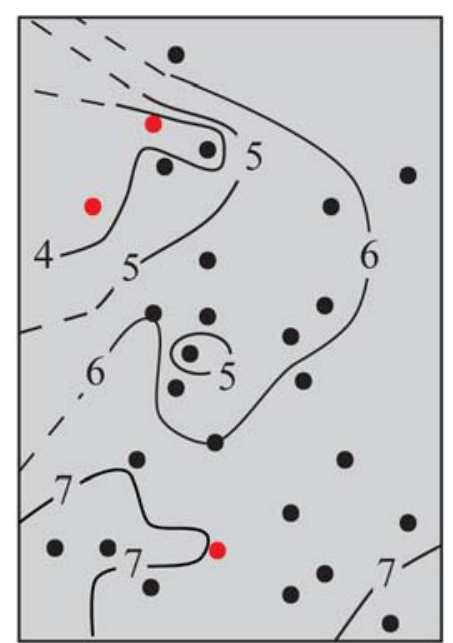

Range: -165 meters to

Range: -645 meters to -645 meters

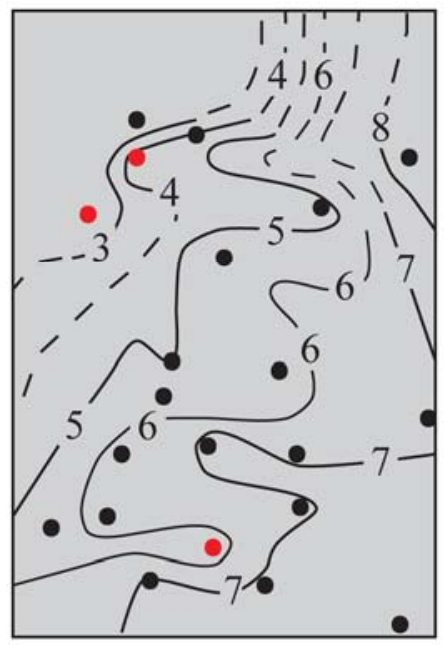

-1125 meters

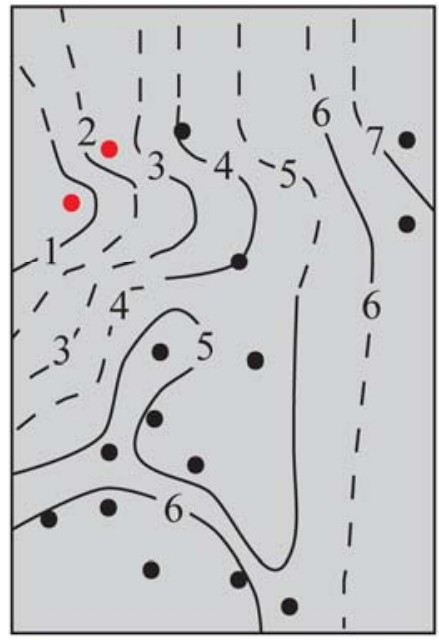

Figure 5: Plan maps of the whole rock oxygen isotope data at a series of elevation intervals in the Coso system. The area of each slice is equal to the area of the West Flank outlined in Figure 1 but the horizontal dimension has been exaggerated for visual clarity. The contour values (in \%) represent averages of the data over $480 \mathrm{~m}$ vertical intervals throughout the field; dashed lines are used where contouring has been inferred. All elevations are relative to sea level. The red and black dots are well locations. The location of transect A-A' in the West Flank is shown in the 224 upper left panel. Contours were generated using the MATLAB contour function. 
225 Nevada Batholith (+7.5 \%o to +9.0\% \% Masi et al., 1981; Lackey et al., 2008) except for depletion

226 to $\delta^{18} \mathrm{O}$ values between $+5 \%$ and $+6 \%$ in the northwest quadrant of the system. With

227 increasing depth, significant and widespread decreases in $\delta^{18} \mathrm{O}$ occur only in the northwest

228 quadrant, where $\delta^{18} \mathrm{O}$ values can decrease down to values between 0 and $+1 \%$ ( -645 to $-1125 \mathrm{~m}$

229 elevation interval). Regardless of depth, the host rock in most of the southern half of the

230 reservoir does not experience significant ${ }^{18} \mathrm{O} /{ }^{16} \mathrm{O}$ depletion below $+5 \%$. At the sampling scale of

231 figure 5, the thermal upflow zones inferred in the SW and NE sectors of the field by Williams

232 and McKibben (1990) are not reflected in significant lowering of $\delta^{18} \mathrm{O}$ values in these sectors.

233 Figure 6 illustrates variations in whole rock $\delta^{18} \mathrm{O}$ values within the vertical section A-A

234 shown in figure 1 (along the West Flank). In general, depletions in ${ }^{18} \mathrm{O} /{ }^{16} \mathrm{O}$ are more extensive

235 and extend to significantly greater depth in the northern portion of the cross-section. In detail,

236 localized intervals of significant ${ }^{18} \mathrm{O} /{ }^{16} \mathrm{O}$ depletion, with less depleted rocks above and below,

237 occur in the northern wells $68-6$ and 33A-7 in intervals centered on elevations of 200, -200 and -

$2381200 \mathrm{~m}$. Maximum depletions to $\delta^{18} \mathrm{O}$ values below $0 \%$ occur in the lowest of these intervals.

239 In contrast, host rocks in the southern part of the traverse are not significantly depleted except for

240 two or three discrete intervals in 73-19 and 58A-18. These spatial patterns of localized and

241 significant ${ }^{18} \mathrm{O} /{ }^{16} \mathrm{O}$ depletions do not reflect the spatial $\delta^{18} \mathrm{O}$ patterns expected from the low and

242 smooth temperature gradients $(\mathrm{dT} / \mathrm{dx})$ characteristic of regional metamorphism. The observed

243 spatial patterns of $\delta^{18} \mathrm{O}$ variation are instead more consistent with localized ${ }^{18} \mathrm{O} /{ }^{16} \mathrm{O}$ depletions

244 expected from fluid-rock interactions related to discrete zones of high permeability associated

245 with geothermal activity.

246 The thermal structure along the cross-section A-A' (Fig. 2) is also superimposed on this

$247 \quad \delta^{18} \mathrm{O}$ cross-section in figure 6 which shows that variations in pre-production temperatures are 


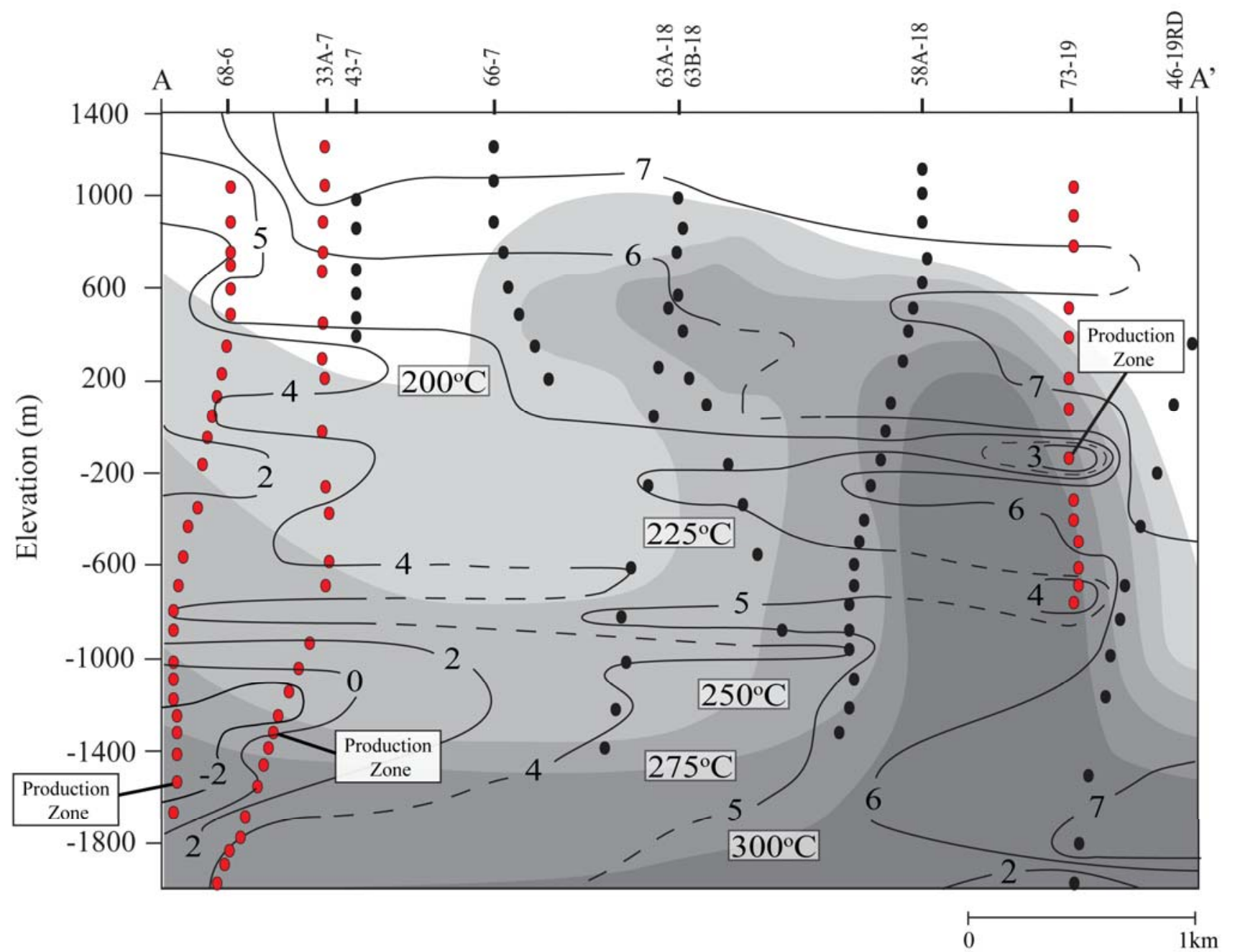

Figure 6: Vertical cross section of the whole rock oxygen isotope data along the north-south transect, A-A'. The locations of the nine wells on or close to the A-A' traverse (fig. 1), and data points from each well used for contouring $\delta^{18} \mathrm{O}$ values are shown; contours are in \%. Red circles indicate the locations of samples analyzed in this study. Isotherms based on preproduction downhole measurements from figure 2 are superimposed to define areas along the cross section above $300{ }^{\circ} \mathrm{C}$ (dark gray) and between $200{ }^{\circ} \mathrm{C}$ and $300{ }^{\circ} \mathrm{C}$ in varying shades of gray; see text for discussion. The major production zone in each well is noted. 
255 not, in general, well correlated with variations in whole-rock $\delta^{18} \mathrm{O}$ values. With the few localized

256 exceptions noted above, the host rocks are not depleted in ${ }^{18} \mathrm{O} /{ }^{16} \mathrm{O}$ to any significant extent in the

257 southern part of the traverse, even within the deeper, higher temperature levels. In the northern

258 part of the section, hotter host rocks below $-1400 \mathrm{~m}$ are less depleted in ${ }^{18} \mathrm{O} /{ }^{16} \mathrm{O}$ than cooler rocks

259 immediately above between -1000 and $-1400 \mathrm{~m}$. However, depth intervals of current production

260 in all three wells do correlate with zones of maximum ${ }^{18} \mathrm{O} /{ }^{16} \mathrm{O}$ depletion (fig. 6). This correlation

261 suggests that permeability plays an important role in controlling the extent of fluid-rock

262 interaction — and hence the extent of ${ }^{18} \mathrm{O} /{ }^{16} \mathrm{O}$ depletion — experienced by the host rocks in the

263 Coso geothermal system.

\section{Oxygen Isotope Characteristics of the West Flank}

265 Whole Rock $\delta^{18} \mathrm{O}$ Analyses. Wells 68-6, 33A-7 and 73-19 were selected for detailed oxygen

266 isotope analyses of whole-rock and mineral separates (table 2; figures 7-9). In well 68-6 (Fig. 7)

267 whole-rock $\delta^{18} \mathrm{O}$ values are somewhat to moderately depleted in ${ }^{18} \mathrm{O} /{ }^{16} \mathrm{O}$ relative to primary

268 igneous values ( +7.5 to $9.0 \%$ ), and fluctuate between $1.8 \%$ and $+6.0 \%$ down to $\sim 2000$ meters

269 depth, with a tendency to decrease with depth. Below $2000 \mathrm{~m},{ }^{18} \mathrm{O} /{ }^{16} \mathrm{O}$ depletions are even

270 greater, and the maximum $\delta^{18} \mathrm{O}$ value is $+3.0 \%$, with most $\delta^{18} \mathrm{O}$ values below $+1 \%$. Whole

271 rock $\delta^{18} \mathrm{O}$ values reach a minimum of $-4.6 \%$ at a 2941 meters below the surface (Fig. 7). In well

$272 \quad 33 \mathrm{~A}-7 \delta^{18} \mathrm{O}$ values generally decrease with depth from a maximum value of $+7.6 \%$ at 33.5

273 meters depth to a minimum of $-3.1 \%$ at 2530 meters, just above the production zone (interval of

274 lost circulation) in the well (Fig. 8). Immediately below, and to the bottom of the well, $\delta^{18} \mathrm{O}$

275 values are significantly higher, ranging between +3 to $+4.9 \%$, but are still significantly lower

276 than primary igneous values. The host rocks in well 73-19 are less depleted in ${ }^{18} \mathrm{O} /{ }^{16} \mathrm{O}$ compared

277 to the rocks of the other two wells (Fig. 9). The highest measured $\delta^{18} \mathrm{O}$ values from whole rock 
278 Table 2: Measured $\delta^{18} \mathrm{O}$ values for whole rock and feldspar mineral samples from well 68-6, 279 Coso geothermal system, California. Values are reported in per mil (\%) notation, relative to 280 VSMOW. Depth is in meters below the surface.

\begin{tabular}{|c|c|c|c|c|c|c|c|c|}
\hline \multicolumn{3}{|c|}{ Well: 68-6 } & \multicolumn{3}{|c|}{ Well: 33A-7 } & \multicolumn{3}{|c|}{ Well: 73-19 } \\
\hline $\begin{array}{l}\text { Depth } \\
\text { (m) }\end{array}$ & $\begin{array}{c}\text { Whole- } \\
\text { Rock } \\
(\%)\end{array}$ & $\begin{array}{c}\text { Feldspar } \\
(\%)\end{array}$ & $\begin{array}{l}\text { Depth } \\
\text { (m) }\end{array}$ & $\begin{array}{c}\text { Whole- } \\
\text { Rock } \\
(\%)\end{array}$ & $\begin{array}{c}\text { Feldspar } \\
(\% 0)\end{array}$ & $\begin{array}{l}\text { Depth } \\
\text { (m) }\end{array}$ & $\begin{array}{c}\text { Whole- } \\
\text { Rock } \\
(\%)\end{array}$ & $\begin{array}{c}\text { Feldspar } \\
(\%)\end{array}$ \\
\hline 271 & 3.88 & & 34 & 7.62 & 7.50 & 271 & 6.98 & 7.79 \\
\hline 335 & 4.47 & 6.04 & 110 & 3.7 & & 381 & 6.61 & \\
\hline 424 & 2.55 & & 262 & 5.39 & & 390 & 6.37 & \\
\hline 488 & 3.49 & 6.59 & 415 & 7.45 & & 445 & 7.48 & 8.12 \\
\hline 564 & 5.08 & & 567 & 4.84 & & 546 & 5.52 & \\
\hline 686 & 5.78 & & 646 & 5.34 & & 777 & 7.57 & \\
\hline 722 & 6.02 & 6.29 & 872 & 0.2 & & 799 & 6.36 & \\
\hline 884 & 3.57 & & 1024 & 3.59 & & 1061 & 7.16 & \\
\hline 985 & 4.07 & & 1100 & 3.00 & 5.49 & 1073 & 7.41 & \\
\hline 1070 & 4.30 & & 1326 & 4.18 & & 1225 & 6.07 & \\
\hline 1271 & 4.43 & & 1570 & 3.89 & & 1317 & 6.63 & \\
\hline 1372 & 2.44 & 5.24 & 1649 & 2.71 & & 1347 & 5.91 & \\
\hline 1433 & 2.87 & & 1878 & 1.03 & & 1387 & 4.61 & 6.14 \\
\hline 1484 & 1.50 & 4.96 & 1984 & 3.93 & & 1411 & 2.38 & \\
\hline 1554 & 2.60 & & 2137 & 1.60 & & 1481 & 6.30 & 7.26 \\
\hline 1701 & 3.78 & 5.64 & 2213 & -0.44 & & 1582 & 5.94 & \\
\hline 1798 & 4.67 & 6.76 & 2323 & -0.02 & & 1664 & 6.85 & \\
\hline 1936 & 4.46 & & 2323 & -1.02 & & 1710 & 5.13 & \\
\hline 2067 & 2.94 & & 2350 & -0.98 & & 1814 & 5.14 & 6.20 \\
\hline 2271 & 2.70 & & 2382 & 0.14 & & 1835 & 3.30 & 6.34 \\
\hline 2393 & 0.75 & & 2472 & 0.51 & -2.37 & 1856 & 3.30 & \\
\hline 2466 & 0.75 & 3.09 & 2502 & -2.35 & & & & \\
\hline 2566 & 0.61 & & 2530 & -3.08 & -0.03 & & & \\
\hline 2710 & 0.75 & 3.08 & & & $+0.63^{*}$ & & & \\
\hline 2792 & 2.83 & 3.59 & 2566 & 0.94 & 4.16 & & & \\
\hline 2850 & 0.54 & & 2594 & 2.15 & 4.20 & & & \\
\hline 2896 & 0.26 & & 2624 & 1.55 & & & & \\
\hline 2941 & -4.60 & -3.88 & 2655 & 2.92 & & & & \\
\hline & & $-5.06^{\#}$ & 2685 & 2.10 & 4.60 & & & \\
\hline & & $-4.12^{*}$ & 2746 & 3.91 & & & & \\
\hline 2984 & -1.05 & 1.76 & 2838 & 4.48 & 5.49 & & & \\
\hline 3173 & 0.64 & & 2960 & 4.60 & & & & \\
\hline & & & 2990 & 4.25 & & & & \\
\hline & & & 3021 & 4.05 & & & & \\
\hline & & & 3051 & 1.78 & & & & \\
\hline & & & 3082 & 4.21 & & & & \\
\hline & & & 3112 & 4.03 & & & & \\
\hline & & & 3143 & 4.61 & & & & \\
\hline & & & 3173 & 4.10 & & & & \\
\hline & & & 3234 & 4.49 & & & & \\
\hline & & & 3295 & 3.88 & 5.90 & & & \\
\hline
\end{tabular}

$281 \quad$ Hand picked cloudy (more altered) feldspar

282 * Feldspar separated from finer-grained (150-200 mesh) whole rock aliquot 


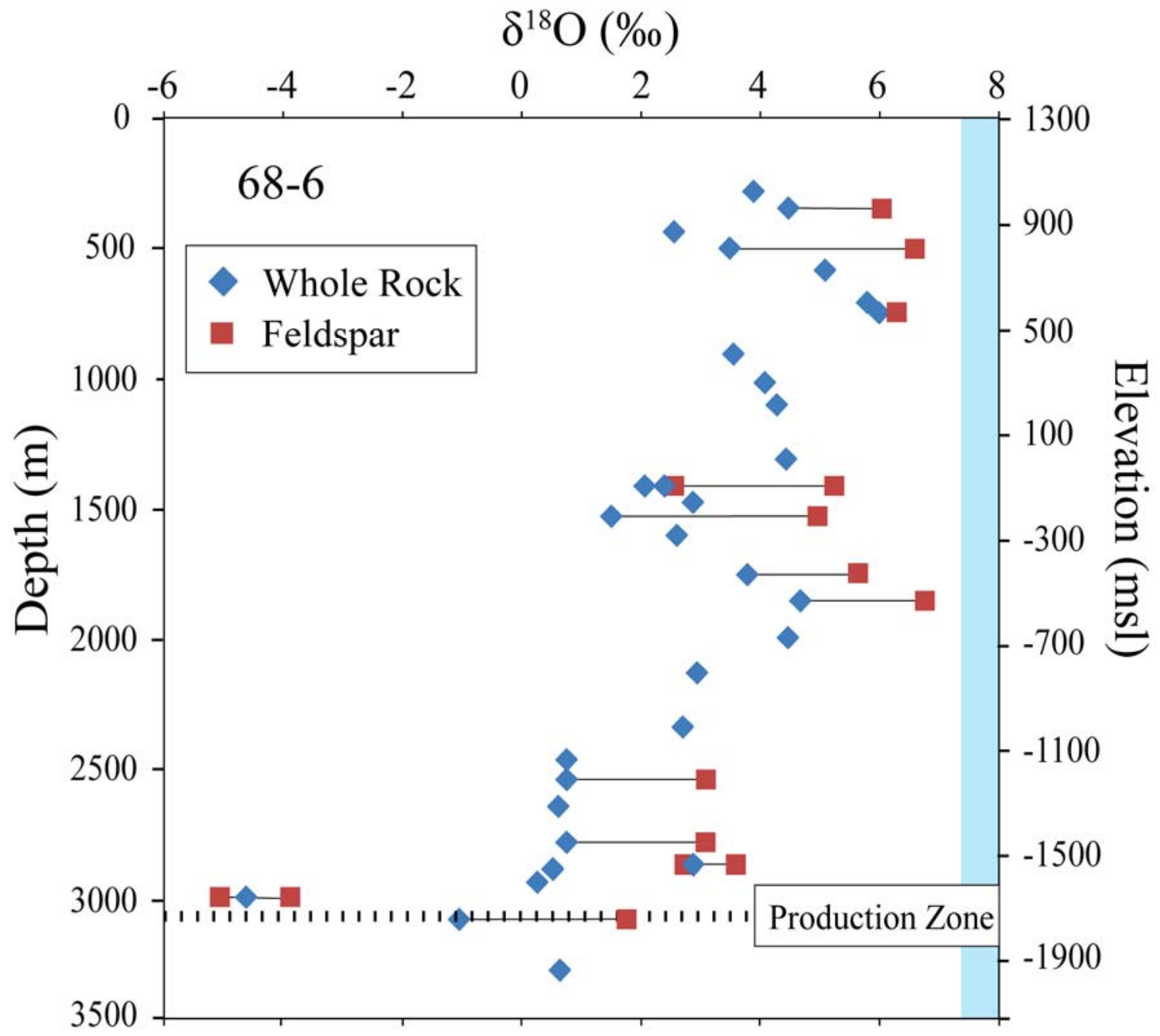

Figure 7: Measured $\delta^{18} \mathrm{O}$ values of whole rock and feldspar samples as a function of depth for well 68-6. All values are reported in per mil (VSMOW), and plotted at both well depth and elevation (meters above sea level). The shaded light blue region here and in figures 8 and 9 represents the range of primary $\delta^{18} \mathrm{O}$ values of diorite to granodiorite rocks from the region that are equivalent to the reservoir host rocks in the Coso system (Lackey et al., 2008). The dotted 290 line marks the current production zone (interval of lost circulation) in 68-6. 


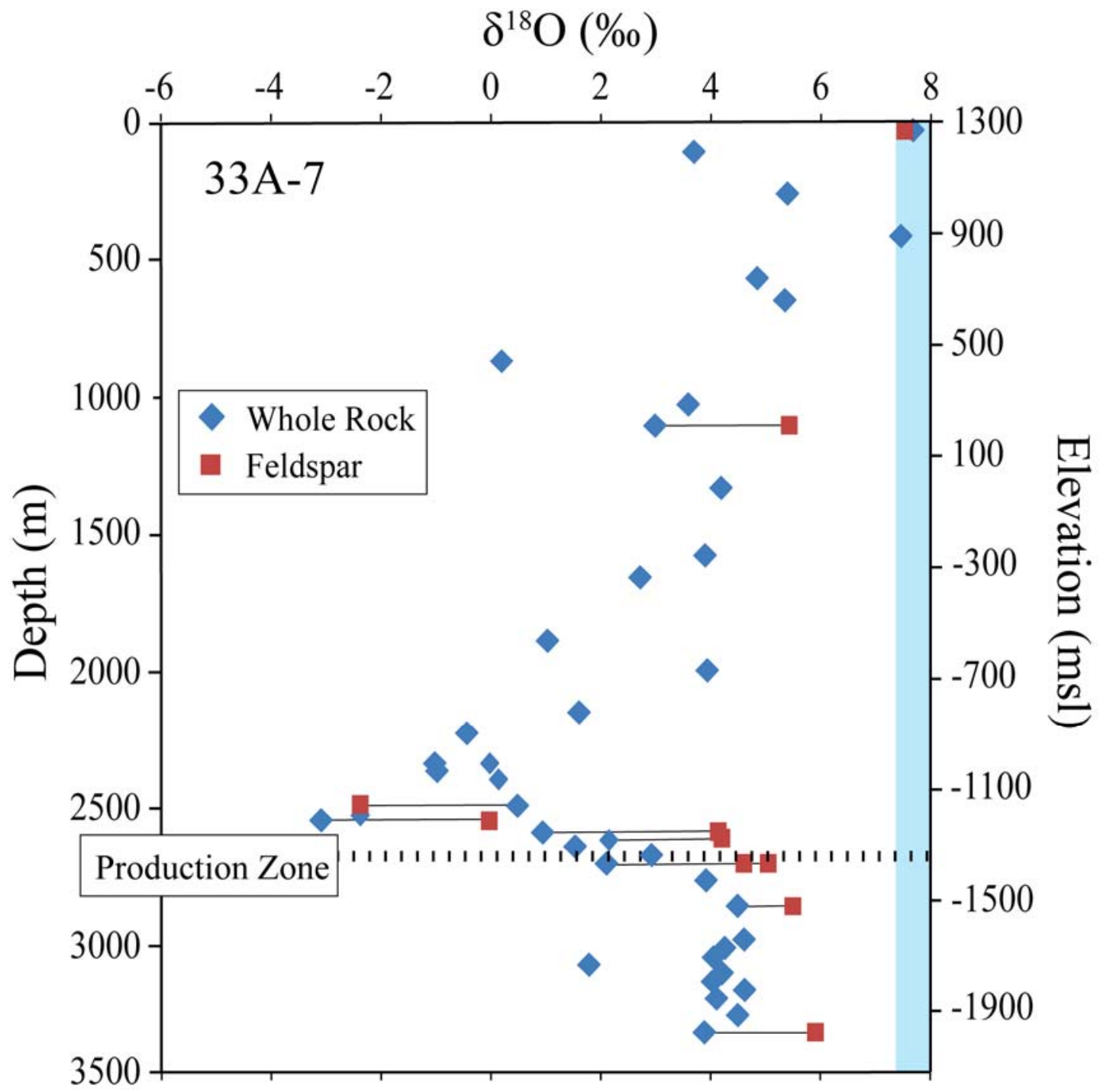

292 Figure 8: Measured $\delta^{18} \mathrm{O}$ values (VSMOW) of whole rock and feldspar samples as a function of 293 well depth and elevation for well 33A-7. The dotted line marks the current production zone 294 (interval of lost circulation) in 33A-7. The shaded light blue region represents the range of 295 primary $\delta^{18} \mathrm{O}$ values of diorite to granodiorite rocks from the region that are equivalent to the 296 297 


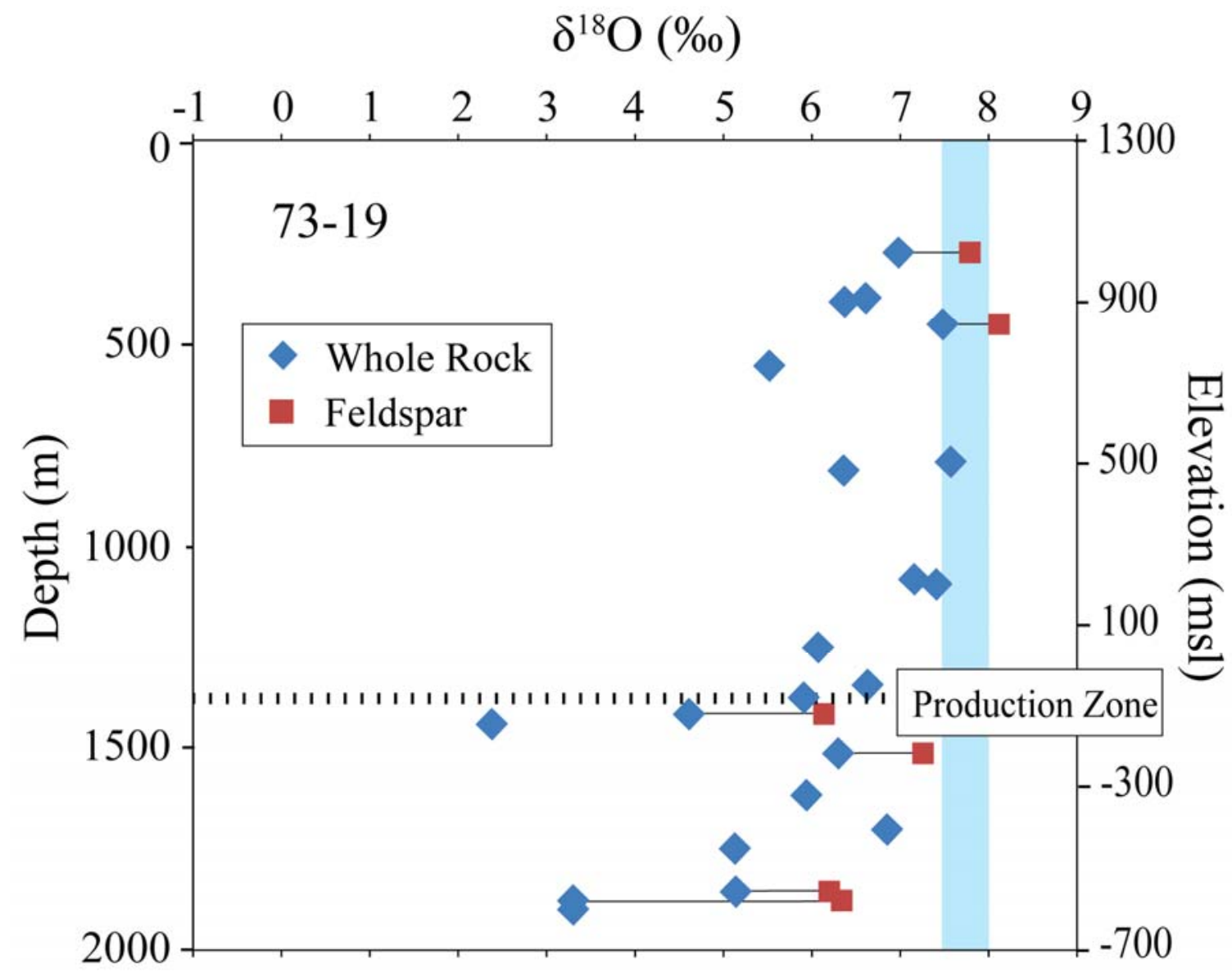

Figure 9: Measured $\delta^{18} \mathrm{O}$ values (VSMOW) of whole rock and feldspar samples as a function of well depth and elevation for well 73-19. The dotted line marks the current production zone (interval of lost circulation) in 73-19. The shaded light blue region represents the range of primary $\delta^{18} \mathrm{O}$ values of diorite to granodiorite rocks from the region that are equivalent to the reservoir host rocks in the Coso system (Lackey et al., 2008).

samples overlap primary igneous $\delta^{18} \mathrm{O}$ values of +7.5 to $9.0 \%$ (Masi et al., 1981; Lackey et al., 2008). The only $\delta^{18} \mathrm{O}$ values below $+5 \%$ occur at depths of $1387 \mathrm{~m}$ and below. The minimum $\delta^{18} \mathrm{O}$ value in well 73-19 is still positive, $+2.4 \%$ (1411 meters depth, Fig. 9). In all three wells, samples with the lowest measured $\delta^{18} \mathrm{O}$ values (or with $\delta^{18} \mathrm{O}_{\mathrm{wr}} \leq 2.0 \%$, well $33 \mathrm{~A}-7$ ) correspond with major intervals of lost circulation, the primary production intervals for each well (Figs. 7-9).

Feldspar vs. Whole Rock Oxygen Isotope Compositions. Measured $\delta^{18} \mathrm{O}$ in bulk feldspar separates range from $6.8 \%$ to $-3.9 \%$ in well $68-6$ and from $7.5 \%$ to $-2.4 \%$ in $33 \mathrm{~A}-7$; feldspars 
312 from well 73-19 have higher $\delta^{18} \mathrm{O}$ values ranging from $8.1 \%$ to $6.1 \%$. In all three wells, the

$313 \delta^{18} \mathrm{O}$ values of the feldspar correlate positively with the whole-rock $\delta^{18} \mathrm{O}$ values, and are

314 systematically 1 to $3 \%$ higher than the whole rock values, even in the more ${ }^{18} \mathrm{O} /{ }^{16} \mathrm{O}$-depleted

315 samples (Figs. 7-9). The only exception is in 33A-7 at $2472 \mathrm{~m}$. The bulk feldspar separates are

316 mixtures of primary (igneous or metamorphic) feldspar and feldspar that has experienced oxygen

317 isotope exchange with geothermal fluid (hydrothermal feldspar). The hydrothermal feldspar

318 should have a considerably lower $\delta^{18} \mathrm{O}$ value than primary feldspar, owing to the low $\delta^{18} \mathrm{O}$ value

319 of the geothermal fluid and intermediate temperature of exchange $\left(\leq 350^{\circ} \mathrm{C}\right)$. Further, feldspar is

320 normally more susceptible to oxygen isotope exchange compared to hornblende and less

321 abundant quartz in the host diorite and quartz diorite (Taylor and Forester, 1979; Criss and

322 Taylor, 1983; Cole et al., 1992). As a result, hydrothermal feldspar might be expected to have a

$323 \delta^{18} \mathrm{O}$ value less than that of the whole-rock for rocks that are only moderately depleted in

$324{ }^{18} \mathrm{O} /{ }^{16} \mathrm{O}$. In thin section, primary igneous and regional metamorphic feldspar are clear and

325 twinned (igneous feldspar); hydrothermal feldspar is cloudy and sometimes turbid from the

326 presence of pits/cavities and very small grains of clay minerals. The intergrown nature of

327 primary and hydrothermal feldspar at the grain scale makes their effective separation by standard

328 density means impractical. However a concentrate of cloudy-looking feldspar was made by hand

329 picking the bulk feldspar separate from sample 68-6_2941. Analysis of this concentrate yielded a

$330 \quad \delta^{18} \mathrm{O}$ value of $-5.1 \%$, significantly lower than the bulk feldspar (-3.9\%o) and whole rock (-4.6

$331 \%$ ) $\delta^{18} \mathrm{O}$ values of this sample (Table 2). In-situ (SIMS) analysis will be necessary to define

332 clearly the $\delta^{18} \mathrm{O}$ value of hydrothermal feldspar in the host rock (e.g., Valley and Graham, 1996;

333 Valley and Kita, 2009). Regardless, this systematic difference between measured $\delta^{18} \mathrm{O}$ values of

334 bulk feldspar and whole rock suggests that the $\delta^{18} \mathrm{O}$ values of both feldspar and whole rock 
335 reflect the extent of interaction (and oxygen isotopic exchange) between host rock and 336 geothermal fluid.

337 Another possibility for the systematic ${ }^{18} \mathrm{O} /{ }^{16} \mathrm{O}$ enrichment in bulk feldspar relative to the 338 whole rock is that the lower $\delta^{18} \mathrm{O}$, hydrothermally altered feldspar was preferentially removed by 339 crushing during preparation of the sample aliquots ( $>80$ or $>100$ mesh size) from the whole rock 340 used to make plagioclase separates. To test this possibility, additional analyses were made of 341 feldspar separated out of the finer-grained (150 to 200 mesh) residual fraction of the whole rock 342 aliquots for two samples. The analyzed $\delta^{18} \mathrm{O}$ values for these finer-grained feldspar separates are $343-4.1 \%$ (compared to -3.9 ) for sample $68-6 \_2941$, and $+0.6 \%$ (compared to -0.0 ) for sample 344 33A-7_2530 (table 2). Additional details of these results are in Etzel (2015). Feldspar separates 345 from these finer-grained fractions are not significantly lower in $\delta^{18} \mathrm{O}$ compared to feldspar 346 separates from the coarser-grained fractions.

347 The systematically higher measured $\delta^{18} \mathrm{O}$ values of feldspar relative to the whole rock 348 indicate, from mass balance considerations, that there is at least one other major phase (likely 349 chlorite and/or other clay mineral alteration products) in the rock that is significantly depleted in $350{ }^{18} \mathrm{O} /{ }^{16} \mathrm{O}$ relative to the whole rock value. Chlorite can replace hornblende but would be stable 351 with biotite during the greenschist facies conditions of the earlier regional metamorphism; this 352 generation of chlorite will not be related to geothermal activity. Replacement of biotite by 353 chlorite would more likely occur at the sub-greenschist facies conditions of the geothermal 354 environment. Hence, bulk separates of chlorite will potentially contain two generations of 355 chlorite of very different $\delta^{18} \mathrm{O}$ value. Good separation of bulk samples of chlorite by magnetic 356 and density methods proved impractical owing to the intergrowth of chlorite with biotite and 357 hornblende at the grain size scale. Concentrates of chloritized biotite from four samples were 
358 handpicked. Their $\delta^{18} \mathrm{O}$ values, compared to whole rock values (in parentheses) are: 1) $0.2 \%$

359 (3.8), sample 68-6_1701; 2) -3.2 \% (0.7), sample 68-6_2710; 3) -3.8 \%о (-3.1), sample 33A-

360 7_2530; and 4) -0.45\% (4.6), sample 73-19_1387. These chloritized biotites are from almost 1

361 to as much as $5 \%$ depleted in ${ }^{18} \mathrm{O} /{ }^{16} \mathrm{O}$ relative to the whole rock values, satisfying at least

362 qualitatively this mass balance requirement. In-situ analyzes will be necessary to define the $\delta^{18} \mathrm{O}$

363 values of the hydrothermal chlorite more precisely.

DISCUSSION

Clay Mineralogy as a Function of Fluid-Rock Interaction

The observed distributions of clay minerals in wells 68-6, 33A-7 and 73-19 are not

367 completely consistent with the pre-production temperatures in these wells (Fig. 3). These

368 discrepancies may indicate that the pre-production thermal regime was different than the regime

369 responsible for clay mineral zoning, and that the clay minerals have not yet re-adjusted to the

370 newer (pre-production) thermal conditions. The persistence of clay minerals outside their normal

371 stability fields (e.g., smectites at $\mathrm{T}>180^{\circ} \mathrm{C}$ in in $73-19$, fig. 3 ) is common but the reasons are

372 poorly understood. Nucleation and reaction kinetics may play roles. In addition permeability,

373 which can either promote (high permeability) or inhibit (low permeability) clay-fluid

374 interactions, may be influencing the spatial distribution of the clay minerals.

375 Oxygen isotope evidence suggests that the extent of fluid-rock interaction experienced by

376 the host rock is influencing the distribution of clay minerals in the Coso system. The amount of

$377{ }^{18} \mathrm{O} /{ }^{16} \mathrm{O}$ depletion is a monitor of the extent of fluid-rock interaction by the host rock - and hence

378 it's permeability. Figure 10 superimposes the distribution of clay minerals in wells $68-6,33 \mathrm{~A}-7$

379 and 73-19 on variations in whole rock $\delta^{18} \mathrm{O}$ values along the cross section $\mathrm{A}-\mathrm{A}^{\prime}$. The host rocks

380 are systematically more depleted in ${ }^{18} \mathrm{O} /{ }^{16} \mathrm{O}$ at depth at the north end compared to the south end 


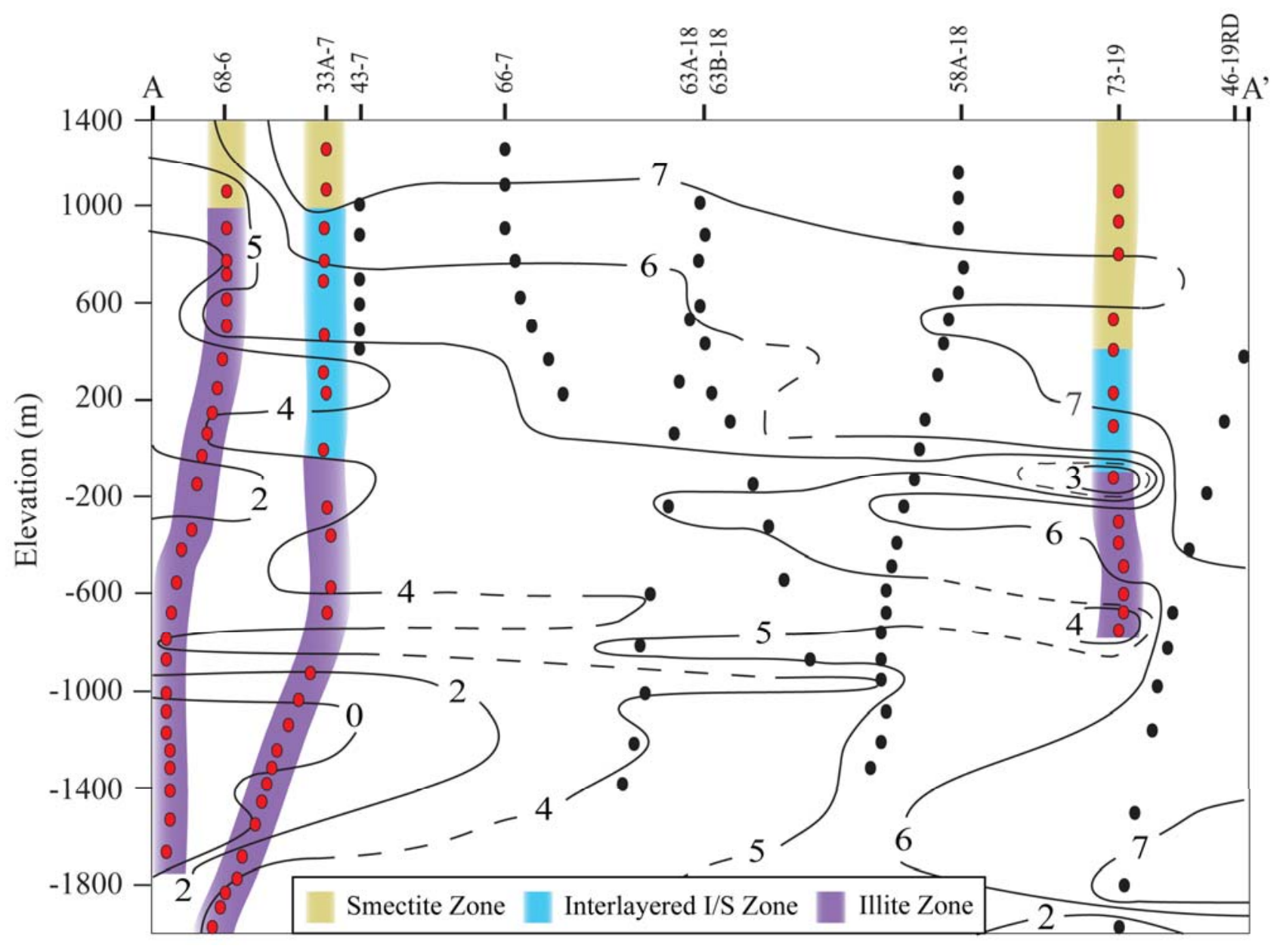

382 Figure 10: Clay zones within wells 68-6, 33A-7 and 73-19 superimposed onto the contoured cross-section of $\delta^{18} \mathrm{O}$ values along the 383 traverse A-A' in the West Flank. Black circles represent intervals with preexisting $\delta^{18} \mathrm{O}$ values, red circles represent intervals where $384 \delta^{18} \mathrm{O}$ values were determined for this study. Increasing extent of ${ }^{18} \mathrm{O} /{ }^{16} \mathrm{O}$ depletion northward correlates with changes in clay mineral 385 zoning with depth, suggesting a correlation between clay mineral stability, extent of fluid-rock interaction and permeability (see text 386 for discussion). 
388 of the traverse. In addition, significant ${ }^{18} \mathrm{O} /{ }^{16} \mathrm{O}$ depletions extend to markedly shallower depth at

389 the north end of A-A'. The overall extent of ${ }^{18} \mathrm{O} /{ }^{16} \mathrm{O}$ depletion in the south third of the traverse is

390 considerably less, and significant ${ }^{18} \mathrm{O} /{ }^{16} \mathrm{O}$ depletions in well $73-19$ are confined to several

391 discrete/narrow/short intervals. Hence in well 73-19 the transition from smectite to interlayered

392 illite/smectite clay is better correlated with temperature, as this transition occurs near the

393 expected temperature of $180^{\circ} \mathrm{C}$ (Fig. 3). However interlayered illite/smectite clay occurs as

394 deeply as $-200 \mathrm{~m}$ elevation $\left(\mathrm{T}=260^{\circ} \mathrm{C}\right.$, Fig. 3 ) in well $73-19$, an elevation corresponding to a

395 local interval of significant ${ }^{18} \mathrm{O} /{ }^{16} \mathrm{O}$ depletion $\left(\delta^{18} \mathrm{O}<4 \%\right.$. Figure 10 shows that there is a

396 general correlation between greater and more spatially widespread ${ }^{18} \mathrm{O} /{ }^{16} \mathrm{O}$ depletion in the north

397 end of A-A' with a thinner smectite zone in $68-6$ and 33A-7 and the lack of a mixed

398 illite/smectite transition zone in 68-6. Additionally, the transition from interlayered illite/smectite

399 to illite clay in 73-19 is correlated with local ${ }^{18} \mathrm{O} /{ }^{16} \mathrm{O}$ depletion. These ${ }^{18} \mathrm{O} /{ }^{16} \mathrm{O}$ depleted zones

400 within traverse A-A' record greater fluid-rock interaction, and are characterized by higher

401 permeability. Hence the extent of fluid-rock interaction (host rock permeability) appears to be

402 controlling, at least in part, the spatial distribution of clay minerals and clay zoning patterns in

403 wells 68-6, 33A-7 and 73-19 along the traverse A-A'.

\section{Oxygen Isotope Exchange and Fluid-Rock Interaction}

405 The $\delta^{18} \mathrm{O}$ values of the whole rock samples from the West Flank range widely from -4.6

$406 \%$ to $7.6 \%$ (table 2). Reservoir rock in 33A-7 and 68-6, except for the shallowest levels, have

407 experienced at least moderate ${ }^{18} \mathrm{O} /{ }^{16} \mathrm{O}$ depletions $\left(\delta^{18} \mathrm{O}<5.0 \%\right.$ ) from primary igneous $\delta^{18} \mathrm{O}$

408 values (+7.5 to 9.0\%). Hence most of the reservoir rock sampled in these two wells has

409 experienced at least some interaction and oxygen isotope exchange with the geothermal reservoir

410 fluid derived from low $\delta^{18} \mathrm{O}$ local meteoric water. Further, a few discrete intervals in 33A-7 and 
$41168-6$ have experienced significantly greater ${ }^{18} \mathrm{O} /{ }^{16} \mathrm{O}$ depletion, and have negative whole-rock

$412 \delta^{18} \mathrm{O}$ values ranging as low as $-4.6 \%$.

413 The extent of ${ }^{18} \mathrm{O} /{ }^{16} \mathrm{O}$ depletion is a function of the amount of reservoir fluid with which

414 the rock has interacted, the temperature and the degree to which isotope exchange equilibrium is

415 attained. Reactive transport models for oxygen isotopes (Baumgartner and Rumble, 1988;

416 Bowman and Willett, 1991; Bowman et al., 1994; Cook et al., 1997; Baumgartner and Valley,

417 2001) have the potential to constrain fluid fluxes, which are related functionally to porosity and

418 permeability. Such transport models are most applicable to interpreting isotopic shifts when the

419 flow geometry of the hydrothermal system is well established and when the locations of the

420 analyzed rocks along the principal flow paths are also known. Person et al. (2006) inferred the

421 basic structure of the regional groundwater system that could have produced the Coso

422 geothermal system. However, the results of our study show that the ${ }^{18} \mathrm{O} /{ }^{16} \mathrm{O}$ depletions recorded

423 in the host rocks of the West Flank are poorly correlated with pre-production temperature

424 patterns and better correlated with known intervals of high permeability (e.g., current fluid

425 production zones)(fig. 6). These relationships suggest that the flow paths from depth and

426 particularly within the West flank reservoir are likely complicated by spatial variations in the

427 permeability of the reservoir host rocks produced by an array of permeable and impermeable

428 fault zones. This is also consistent with geochemical and enthalpy data from well tests that

429 suggest that the Coso field is divided into a series of hydrologically isolated (fault bounded?),

430 single-phase reservoirs (Williams and McKibben, 1990). As a result, the fracture-controlled and

431 channelized flow patterns responsible for the localized ${ }^{18} \mathrm{O} /{ }^{16} \mathrm{O}$ depletions measured in the West

432 Flank host rocks (this study) are not yet well understood. Hence application of transport models

433 to interpret these ${ }^{18} \mathrm{O} /{ }^{16} \mathrm{O}$ depletions will be problematic without additional information on the 
434 geometry of these fracture networks. Given such complications, estimates of the minimum

435 amounts of fluid involved in isotopic exchange can be been made using conventional box models 436 of mass balance to compute water (W) to rock (R) ratios (Taylor, 1971).

437 Calculations of box model W/R ratios involve several assumptions, and it is important to 438 understand how these assumptions place limitations on their interpretation. Both closed- and 439 open-system box model endmembers (Taylor, 1971; Criss and Taylor, 1986) assume attainment 440 of exchange equilibrium between rock and fluid. Incomplete exchange yields less ${ }^{18} \mathrm{O} /{ }^{16} \mathrm{O}$ 441 depletion in a rock; this will result in lower calculated W/R ratios. Departures from equilibrium 442 may be important in geothermal systems that form at temperatures less than $300{ }^{\circ} \mathrm{C}$, and 443 particularly so in their shallow, lower temperature sections. Disequilibrium is demonstrated at 444 Coso by the large differences in measured $\delta^{18} \mathrm{O}$ values between hydrothermal vs. igneous 445 minerals such as feldspar and chlorite, and between reservoir fluid and host rock.

446 A second limitation is that box model W/R calculations do not account for the isotopic 447 modification that the fluid undergoes along segments of its flow paths leading to the local site of 448 hydrothermal alteration and isotopic exchange (Baumgartner and Rumble, 1988; Bowman and 449 Willett, 1991; Bowman et al., 1994). The impact of this prior exchange history of the fluid is that 450 box model $\mathrm{W} / \mathrm{R}$ ratios will underestimate actual $\mathrm{W} / \mathrm{R}$ ratios by an amount that increases with 451 increasing distance along the reactive flow path. The actual amount of fluid involved might have 452 been orders of magnitude higher. As a result, calculated box model W/R ratios should be 453 regarded as minimum estimates of the amounts of fluid involved in hydrothermal alteration and 454 isotopic exchange at specific sites within hydrothermal flow systems. Meteoric waters recharging 455 the Coso geothermal reservoir have experienced considerable ${ }^{18} \mathrm{O} /{ }^{16} \mathrm{O}$ enrichment, likely 456 resulting from fluid-rock exchange within the deeper, hotter portions of the Coso hydrologic 
system (Person et al., 2006). However, the geothermal fluids are still well out of oxygen isotope

458 exchange equilibrium with the reservoir host rocks at temperatures from 200 to $350^{\circ} \mathrm{C}$. As a

459 result, these fluids are still chemically (isotopically) reactive, and are capable of producing

460 significant ${ }^{18} \mathrm{O} /{ }^{16} \mathrm{O}$ depletions in the infiltrated rocks. Consequently, variations in the extent of

$461{ }^{18} \mathrm{O} /{ }^{16} \mathrm{O}$ depletion in rocks from local segments of the Coso hydrothermal system — and variations

462 in calculated W/R ratios - will qualitatively reflect variations in fluid fluxes. Hence, the W/R

463 ratios calculated from oxygen isotope ratios are expected to reflect the relative differences in

464 permeability and time-integrated fluid flux for these local segments.

465 Calculated W/R ratios (atomic oxygen) using both closed and open system box models

466 (Taylor, 1971; Criss and Taylor, 1986) are presented in tables 3-5. The average $\delta^{18} \mathrm{O}$ value of

467 local meteoric water (geothermal fluid source) with similar $\delta \mathrm{D}$ values (-96 to $-104 \%$ ) to those of

468 the pre-production reservoir fluids is $\sim-13 \%$ (Williams and McKibben, 1990). The $\delta^{18} \mathrm{O}$ values

469 of the pre-production reservoir fluids were determined using measured temperature, pressure and

$470 \quad \delta^{18} \mathrm{O}$ values of the separated vapor (steam) and liquid water sampled during pre-production flow

471 tests in each well (unpublished data, Terra-Gen Operating Company), following the heat and

472 mass balance calculations described by Truesdell (1984). Use of samples from pre-production

473 flow tests avoids the impact on the calculated $\delta^{18} \mathrm{O}$ values of the reservoir fluids of any ${ }^{18} \mathrm{O} /{ }^{16} \mathrm{O}$

474 enrichment from steam loss during subsequent power production. In all following discussion, the

$475 \delta^{18} \mathrm{O}$ values of the reservoir fluid refer to the calculated $\delta^{18} \mathrm{O}$ values of the pre-production fluids.

476 The $\delta^{18} \mathrm{O}$ measurements identify a limited number of localized intervals of much more

477 extensive ${ }^{18} \mathrm{O} /{ }^{16} \mathrm{O}$ depletion within the reservoir host rocks that have interacted and exchanged

478 isotopically with significantly larger quantities of geothermal fluid (higher calculated W/R

479 ratios). Well 33A-7 has three such intervals of locally higher calculated W/R ratios at 2502 - 
480 481

Table 3: Calculated equilibrium $\Delta_{\mathrm{r} \text {-w }}$ and $\Delta_{\text {fsp-w }}$, measured $\Delta_{\mathrm{r} \text {-w }}$ and $\Delta_{\text {fsp-w }}$, and W/R ratios for well 68-6. WR = whole-rock; Eq = equilibrium; FSP = feldspar.

\begin{tabular}{|c|c|c|c|c|c|c|c|c|}
\hline $\begin{array}{c}68-6 \\
\text { ID }\end{array}$ & $\begin{array}{l}\text { W.R. } \\
\delta^{18} \mathrm{O}\end{array}$ & $\begin{array}{c}E q \\
\Delta_{\mathrm{r}-\mathrm{w}}{ }^{1}\end{array}$ & $\begin{array}{c}\text { Measured } \\
\Delta_{\mathrm{r}-\mathrm{w}}{ }^{2}\end{array}$ & $\begin{array}{l}F S P \\
\delta^{18} \mathrm{O}\end{array}$ & $\begin{array}{c}E q \\
\Delta \Delta_{\text {fsp-w }} 1 \\
\end{array}$ & $\begin{array}{c}\text { Measured } \\
\Delta_{\text {fsp-w }}{ }^{2}\end{array}$ & $\begin{array}{c}\mathrm{W} / \mathrm{R} \\
\text { closed }\end{array}$ & $\begin{array}{c}\mathrm{W} / \mathrm{R} \\
\text { Open }\end{array}$ \\
\hline 271 & 3.88 & 9.33 & 12.55 & & & & 0.49 & 0.40 \\
\hline 335 & 4.47 & 9.33 & 13.14 & 6.04 & 10.17 & 14.71 & 0.36 & 0.31 \\
\hline 424 & 2.55 & 9.33 & 11.22 & & & & 0.80 & 0.59 \\
\hline 488 & 3.49 & 9.27 & 12.16 & 6.59 & 10.10 & 15.26 & 0.58 & 0.46 \\
\hline 564 & 5.08 & 9.27 & 13.75 & & & & 0.22 & 0.20 \\
\hline 686 & 5.78 & 9.03 & 14.45 & & & & 0.06 & 0.05 \\
\hline 722 & 6.02 & 8.79 & 14.69 & 6.29 & 9.59 & 14.96 & 0.00 & 0.00 \\
\hline 884 & 3.57 & 8.04 & 12.24 & & & & 0.57 & 0.45 \\
\hline 985 & 4.07 & 7.68 & 12.74 & & & & 0.45 & 0.37 \\
\hline 1070 & 4.30 & 7.36 & 12.97 & & & & 0.40 & 0.33 \\
\hline 1271 & 4.43 & 7.36 & 13.10 & & & & 0.37 & 0.31 \\
\hline 1372 & 2.44 & 6.81 & 11.11 & 5.24 & 7.46 & 13.91 & 0.83 & 0.60 \\
\hline 1433 & 2.87 & 6.81 & 11.54 & & & & 0.73 & 0.55 \\
\hline 1484 & 1.50 & 6.81 & 10.17 & 4.96 & 7.46 & 13.63 & 1.04 & 0.71 \\
\hline 1554 & 2.60 & 6.81 & 11.27 & & & & 0.79 & 0.58 \\
\hline 1701 & 3.78 & 6.72 & 12.45 & 5.64 & 7.37 & 14.31 & 0.52 & 0.42 \\
\hline 1798 & 4.67 & 6.51 & 13.34 & 6.76 & 7.13 & 15.43 & 0.31 & 0.27 \\
\hline 1936 & 4.46 & 6.38 & 13.13 & & & & 0.36 & 0.31 \\
\hline 2067 & 2.94 & 6.30 & 11.61 & & & & 0.71 & 0.54 \\
\hline 2271 & 2.70 & 6.06 & 11.37 & & & & 0.77 & 0.57 \\
\hline 2393 & 0.75 & 5.94 & 9.42 & & & & 1.22 & 0.80 \\
\hline 2466 & 0.75 & 5.88 & 9.42 & 3.09 & 6.46 & 11.76 & 1.22 & 0.80 \\
\hline 2566 & 0.61 & 5.79 & 9.28 & & & & 1.25 & 0.81 \\
\hline 2710 & 0.75 & 5.50 & 9.42 & 3.08 & 6.05 & 11.75 & 1.22 & 0.80 \\
\hline 2792 & 2.83 & 5.60 & 11.50 & 3.59 & 6.16 & 12.26 & 0.74 & 0.55 \\
\hline 2850 & 0.54 & 5.77 & 9.21 & & & & 1.27 & 0.82 \\
\hline 2896 & 0.26 & 5.98 & 8.93 & & & & 1.33 & 0.85 \\
\hline 2941 & -4.60 & 5.98 & 4.07 & -3.88 & 6.57 & 4.79 & 2.45 & 1.24 \\
\hline 2984 & -1.05 & 5.73 & 7.62 & 1.76 & 6.30 & 10.43 & 1.63 & 0.97 \\
\hline 3173 & 0.64 & 5.00 & 9.31 & & & & 1.24 & 0.81 \\
\hline
\end{tabular}

482

483

484

485

486

487

488

489

490

491

492

493
${ }^{1}$ Equilibrium $\Delta_{\mathrm{r}-\mathrm{w}}$ and $\Delta_{\text {fsp-w }}$ fractionation values calculated at pre-production reservoir temperatures using the experimental fractionation factor for An 50 -water and An25-water (O'Neil and Taylor, 1967), respectively.

${ }^{2}$ Measured $\Delta_{\text {wr-w }}$ and $\Delta_{\text {fsp-w }}$ are the differences between the measured $\delta^{18} \mathrm{O}$ values of whole-rock or feldspar, and the measured $\delta^{18} \mathrm{O}$ value of the current geothermal fluid $(-8.67 \%$ ). 
494 Table 4: Calculated equilibrium $\Delta_{\mathrm{r}-\mathrm{w}}$ and $\Delta_{\text {fsp-w }}$, measured $\Delta_{\mathrm{r}-\mathrm{w}}$ and $\Delta_{\text {fsp-w }}$, and W/R ratios for well 495 33A-7. WR = whole-rock; $\mathrm{Eq}=$ equilibrium; FSP $=$ feldspar.

\begin{tabular}{|c|c|c|c|c|c|c|c|c|}
\hline $\begin{array}{c}33 \mathrm{~A}-7 \\
\text { ID }\end{array}$ & $\begin{array}{l}\text { W.R. } \\
\delta^{18} \mathrm{O}\end{array}$ & $\begin{array}{c}E q \\
\Delta_{\mathrm{r}-\mathrm{w}}\end{array}$ & $\begin{array}{c}\text { Measured } \\
\Delta_{\mathrm{r}-\mathrm{w}}{ }^{2}\end{array}$ & $\begin{array}{l}F S P \\
\delta^{18} \mathrm{O}\end{array}$ & $\begin{array}{c}E q \\
\Delta_{\text {fsp-w }} 1\end{array}$ & $\begin{array}{c}\text { Measured } \\
\Delta_{\text {fsp-w }}^{2}\end{array}$ & $\begin{array}{l}\mathrm{W} / \mathrm{R} \\
\text { closed }\end{array}$ & $\begin{array}{l}\text { W/R } \\
\text { Open }\end{array}$ \\
\hline 34 & 7.62 & 23.44 & 15.11 & 7.50 & 25.34 & 14.99 & 0.00 & 0.00 \\
\hline 110 & 3.7 & 19.54 & 11.19 & & & & 0.71 & 0.54 \\
\hline 262 & 5.39 & 14.03 & 12.88 & & & & 0.40 & 0.34 \\
\hline 415 & 7.45 & 11.00 & 14.94 & & & & 0.03 & 0.03 \\
\hline 567 & 4.84 & 11.00 & 12.33 & & & & 0.50 & 0.41 \\
\hline 646 & 5.34 & 9.78 & 12.83 & & & & 0.41 & 0.35 \\
\hline 872 & 0.2 & 9.30 & 7.69 & & & & 1.35 & 0.85 \\
\hline 1024 & 3.59 & 8.70 & 11.08 & & & & 0.73 & 0.55 \\
\hline 1100 & 3 & 8.56 & 10.49 & 5.49 & 9.34 & 12.98 & 0.84 & 0.61 \\
\hline 1326 & 4.18 & 8.20 & 11.67 & & & & 0.62 & 0.49 \\
\hline 1570 & 3.89 & 7.94 & 11.38 & & & & 0.68 & 0.52 \\
\hline 1649 & 2.71 & 7.76 & 10.20 & & & & 0.89 & 0.64 \\
\hline 1878 & 1.03 & 7.39 & 8.52 & & & & 1.20 & 0.79 \\
\hline 1984 & 3.93 & 7.20 & 11.42 & & & & 0.67 & 0.51 \\
\hline 2137 & 1.6 & 6.81 & 9.09 & & & & 1.09 & 0.74 \\
\hline 2213 & -0.44 & 6.70 & 7.05 & & & & 1.46 & 0.90 \\
\hline 2323 & -0.02 & 6.49 & 7.47 & & & & 1.39 & 0.87 \\
\hline 2323 & -1.02 & 6.49 & 6.47 & & & & 1.57 & 0.94 \\
\hline 2350 & -0.98 & 6.44 & 6.51 & & & & 1.56 & 0.94 \\
\hline 2382 & 0.14 & 6.38 & 7.63 & & & & 1.36 & 0.86 \\
\hline 2472 & 0.51 & 6.18 & 8.00 & -2.37 & 6.78 & 5.12 & 1.29 & 0.83 \\
\hline 2502 & -2.35 & 6.06 & 5.14 & & & & 1.81 & 1.03 \\
\hline 2530 & -3.08 & 6.02 & 4.41 & -0.03 & 6.61 & 7.46 & 1.94 & 1.08 \\
\hline 2566 & 0.94 & 6.02 & 8.43 & 4.16 & 6.61 & 11.65 & 1.21 & 0.79 \\
\hline 2594 & 2.15 & 5.96 & 9.64 & 4.20 & 6.55 & 11.69 & 0.99 & 0.69 \\
\hline 2624 & 1.55 & 5.85 & 9.04 & & & & 1.10 & 0.74 \\
\hline 2655 & 2.92 & 5.79 & 10.41 & & & & 0.85 & 0.62 \\
\hline 2685 & 2.1 & 5.73 & 9.59 & 4.60 & 6.30 & 12.09 & 1.00 & 0.69 \\
\hline 2746 & 3.91 & 5.60 & 11.40 & & & & 0.67 & 0.51 \\
\hline 2838 & 4.48 & 5.48 & 11.97 & 5.49 & 6.03 & 12.98 & 0.57 & 0.45 \\
\hline 2960 & 4.6 & 5.25 & 12.09 & & & & 0.55 & 0.44 \\
\hline
\end{tabular}

496

${ }^{1}$ Equilibrium $\Delta_{\mathrm{r}-\mathrm{w}}$ and $\Delta_{\text {fsp-w }}$ fractionation values calculated at pre-production reservoir temperatures using the experimental fractionation factor for An50-water and An25-water (O'Neil and Taylor, 1967), respectively.

${ }^{2}$ Measured $\Delta_{\text {wr-w }}$ and $\Delta_{\text {fsp-w }}$ are the differences between the measured $\delta^{18} \mathrm{O}$ values of whole-rock or feldspar, and the measured $\delta^{18} \mathrm{O}$ value of the current geothermal fluid $(-7.49 \%$ ).

502

503

504

505

506 
Table 4 (continued): Calculated equilibrium $\Delta_{\mathrm{r}-\mathrm{w}}$ and $\Delta_{\text {fsp-w }}$, measured $\Delta_{\mathrm{r}-\mathrm{w}}$ and $\Delta_{\text {fsp-w }}$, and W/R 508 ratios for well 33A-7. WR = whole-rock; $\mathrm{Eq}=$ equilibrium; $\mathrm{FSP}=$ feldspar.

\begin{tabular}{ccccccccc}
\hline $33 \mathrm{~A}-7$ & W.R. & $E q$ & Measured & $F S P$ & $E q$ & Measured & $\begin{array}{c}\mathrm{W} / \mathrm{R} \\
\text { closed }\end{array}$ & $\begin{array}{c}\mathrm{W} / \mathrm{R} \\
\text { Open }\end{array}$ \\
\hline 2990 & 4.25 & 5.20 & 11.74 & & & & 0.61 & 0.48 \\
3021 & 4.05 & 5.16 & 11.54 & & & & 0.65 & 0.50 \\
3051 & 1.78 & 5.13 & 9.27 & & & & 1.06 & 0.72 \\
3082 & 4.21 & 5.13 & 11.70 & & & & 0.62 & 0.48 \\
3112 & 4.03 & 5.00 & 11.52 & & & & 0.65 & 0.50 \\
3143 & 4.61 & 4.95 & 12.10 & & & & 0.55 & 0.44 \\
3173 & 4.1 & 4.84 & 11.59 & & & & 0.64 & 0.49 \\
3234 & 4.49 & 4.76 & 11.98 & & & & 0.57 & 0.45 \\
3295 & 3.88 & 4.68 & 11.37 & 5.90 & 5.17 & 13.39 & 0.68 & 0.52 \\
\hline
\end{tabular}

${ }^{1}$ Equilibrium $\Delta_{\mathrm{r} \text {-w }}$ and $\Delta_{\text {fsp-w }}$ fractionation values calculated at pre-production reservoir 511 temperatures using the experimental fractionation factor for $\mathrm{An}_{50}$-water and $\mathrm{An}_{25}$-water (O'Neil 512 and Taylor, 1967), respectively.

$513{ }^{2}$ Measured $\Delta_{\mathrm{wr}-\mathrm{w}}$ and $\Delta_{\text {fsp-w }}$ are the differences between the measured $\delta^{18} \mathrm{O}$ values of whole rock 514 or feldspar, and the measured $\delta^{18} \mathrm{O}$ value of the current geothermal fluid $(-7.49 \%)$. 
516 Table 5: Calculated equilibrium $\Delta_{\mathrm{r}-\mathrm{w}}$ and $\Delta_{\text {fsp-w }}$, measured $\Delta_{\mathrm{r}-\mathrm{w}}$ and $\Delta_{\text {fsp-w }}$, and W/R ratios for well 517 73-19. WR = whole-rock; Eq = equilibrium; FSP $=$ feldspar.

\begin{tabular}{|c|c|c|c|c|c|c|c|c|}
\hline $\begin{array}{c}73-19 \\
\text { ID }\end{array}$ & $\begin{array}{l}\text { W.R. } \\
\delta^{18} \mathrm{O}\end{array}$ & $\begin{array}{c}E q \\
\Delta_{\mathrm{r}-\mathrm{w}} \\
\end{array}$ & $\begin{array}{l}\text { Measured } \\
\Delta_{\mathrm{r}-\mathrm{w}}{ }^{2}\end{array}$ & $\begin{array}{l}F S P \\
\delta^{18} \mathrm{O}\end{array}$ & $\begin{array}{c}E q \\
\Delta_{\text {fsp-w }} 1 \\
\end{array}$ & $\begin{array}{l}\text { Measured } \\
\Delta_{\text {fsp-w }}^{2}\end{array}$ & $\begin{array}{l}\mathrm{W} / \mathrm{R} \\
\text { closed }\end{array}$ & $\begin{array}{l}\mathrm{W} / \mathrm{R} \\
\text { Open }\end{array}$ \\
\hline 271 & 6.98 & 16.10 & 12.54 & 7.79 & 17.43 & 13.35 & 0.08 & 0.08 \\
\hline 381 & 6.61 & 14.08 & 12.17 & & & & 0.13 & 0.12 \\
\hline 390 & 6.37 & 14.03 & 11.93 & & & & 0.16 & 0.15 \\
\hline 445 & 7.48 & 13.35 & 13.04 & 8.12 & 14.47 & 13.68 & 0.01 & 0.01 \\
\hline 546 & 5.52 & 11.78 & 11.08 & & & & 0.28 & 0.24 \\
\hline 777 & 7.57 & 8.85 & 13.13 & & & & 0.00 & 0.00 \\
\hline 799 & 6.36 & 8.62 & 11.92 & & & & 0.16 & 0.15 \\
\hline 1061 & 7.16 & 6.37 & 12.72 & & & & 0.06 & 0.05 \\
\hline 1073 & 7.41 & 6.25 & 12.97 & & & & 0.02 & 0.02 \\
\hline 1225 & 6.07 & 5.47 & 11.63 & & & & 0.20 & 0.18 \\
\hline 1317 & 6.63 & 5.12 & 12.19 & & & & 0.13 & 0.12 \\
\hline 1347 & 5.91 & 5.12 & 11.47 & & & & 0.22 & 0.20 \\
\hline 1387 & 4.61 & 4.92 & 10.17 & 6.14 & 5.42 & 11.70 & 0.40 & 0.33 \\
\hline 1411 & 2.38 & 5.00 & 7.94 & & & & 0.70 & 0.53 \\
\hline 1481 & 6.3 & 4.69 & 11.86 & 7.26 & 5.18 & 12.82 & 0.17 & 0.16 \\
\hline 1582 & 5.94 & 4.55 & 11.50 & & & & 0.22 & 0.20 \\
\hline 1664 & 6.85 & 4.39 & 12.41 & & & & 0.10 & 0.09 \\
\hline 1710 & 5.13 & 4.26 & 10.69 & & & & 0.33 & 0.28 \\
\hline 1814 & 5.14 & 4.63 & 10.70 & 6.20 & 4.69 & 11.76 & 0.33 & 0.28 \\
\hline 1835 & 3.3 & 4.95 & 8.86 & 6.34 & 4.69 & 11.90 & 0.57 & 0.45 \\
\hline 1856 & 3.3 & 4.86 & 8.86 & & & & 0.57 & 0.45 \\
\hline
\end{tabular}

${ }^{1}$ Equilibrium $\Delta_{\mathrm{r}-\mathrm{w}}$ and $\Delta_{\text {fsp-w }}$ fractionation values calculated at pre-production reservoir

520 temperatures using the experimental fractionation factor for An50-water and An25-water (O'Neil 521 and Taylor, 1967), respectively.

$522{ }^{2}$ Measured $\Delta_{\text {wr-w }}$ and $\Delta_{\text {fsp-w }}$ are the differences between the measured $\delta^{18} \mathrm{O}$ values of whole-rock 523 or feldspar, and the measured $\delta^{18} \mathrm{O}$ value of the current geothermal fluid $(-5.56 \%$ ). 
$2530 \mathrm{~m}\left[(\mathrm{~W} / \mathrm{R})_{\mathrm{c}}=1.94\right]$; at $872 \mathrm{~m}\left[(\mathrm{~W} / \mathrm{R})_{\mathrm{c}}=1.35\right]$; and at $110 \mathrm{~m}\left[(\mathrm{~W} / \mathrm{R})_{\mathrm{c}}=0.71\right]$. Well 68-6 has

527 one interval at $2941 \mathrm{~m}$ that is characterized by much higher $\mathrm{W} / \mathrm{R}$ ratio $\left[(\mathrm{W} / \mathrm{R})_{\mathrm{c}}=2.45\right]$ than

528 elsewhere in the well. In general, calculated W/R ratios for 73-19 are lower than for the other

529 two wells, suggesting that permeability in this well is generally lower than in 68-6 and 33A-7.

530 However locally higher W/R ratios (closed system) are computed for depths of $1856(0.57), 1835$

531 (0.57), $1412(0.70)$ and $546(0.28)$ meters in well 73-19. The presence of these limited number of

532 discrete intervals of significant ${ }^{18} \mathrm{O} /{ }^{16} \mathrm{O}$ depletion (and high calculated $\mathrm{W} / \mathrm{R}$ ratios) in the three

533 wells reflect discrete zones of much higher permeability within low permeability (much less

$534{ }^{18} \mathrm{O} /{ }^{16} \mathrm{O}$ depleted) rock. This spatial pattern is consistent with fluid flow that is focused along

535 discrete fractures. In all three wells, the depths of current reservoir fluid production, which are

536 represented by zones of lost circulation and high permeability, correspond to one of these

537 intervals of significant ${ }^{18} \mathrm{O} /{ }^{16} \mathrm{O}$ depletion —and high $\mathrm{W} / \mathrm{R}$ ratio (figures 7-9).

The Extent of Isotope Exchange Equilibrium Accompanying Fluid-Rock Interaction

Because the pre-production temperatures of the reservoir fluids are known, the

541 equilibrium oxygen isotope fractionations between feldspar and water (equilibrium $\Delta_{\text {fsp-w }}$ ) can be

542 calculated. These values can be compared to the measured differences in $\delta^{18} \mathrm{O}$ between feldspar

543 and the reservoir fluids (measured $\Delta_{\text {fsp-w }}$ ) (tables 3-5) to evaluate the extent of exchange

544 equilibrium between the geothermal fluid and feldspar in the reservoir host rocks. If feldspar has

545 incompletely exchanged oxygen isotopes with the low $\delta^{18} \mathrm{O}$ geothermal fluid at temperatures

546 below $500{ }^{\circ} \mathrm{C}$, measured $\Delta_{\text {fsp-w }}$ values will be greater than the equilibrium $\Delta_{\text {fsp-w }}$ values. The

547 greater this difference, the farther from exchange equilibrium is the feldspar. The equilibrium

548 fractionation factors are calculated at temperatures measured in the wells prior to production, 
using the experimental calibration for oxygen isotope fractionation between plagioclase and water from O’Neil and Taylor (1967) and a plagioclase composition of An25 (average of measured feldspar compositions in the reservoir rocks; Etzel, 2015).

Figure 11a depicts the measured $\delta^{18} \mathrm{O}$ values of feldspar plotted against the difference

553 between measured $\Delta_{\text {fsp-w }}$ and equilibrium $\Delta_{\text {fsp-w }}$ values. This figure illustrates that the measured

$554 \Delta_{\text {fsp-w }}$ values for most of the sampled intervals are larger than equilibrium $\Delta_{\text {fsp-w }}$ values at

555 measured (pre-production) temperatures and plot to the right of the dashed line (where measured

$556 \Delta_{\text {fsp-w }}=$ equilibrium $\left.\Delta_{\text {fsp-w }}\right)$ in figure 11a. This difference indicates that feldspars from most of the

557 sampled intervals in these three wells have not completely exchanged with the geothermal fluid.

558 Two groups of samples with measured $\Delta_{\text {fsp-w }}$ values less than equilibrium $\Delta_{\text {fsp-w }}$ are exceptions.

559 The three feldspar samples with $\delta^{18} \mathrm{O}$ values $>7.0 \%$ come from the shallowest, lowest

560 temperature intervals of 33A-7 and 73-19 and have experienced little or no ${ }^{18} \mathrm{O} /{ }^{16} \mathrm{O}$ depletion

561 relative to their primary $\delta^{18} \mathrm{O}$ values. As a result, these feldspars have not experienced any

562 significant interaction with geothermal fluid, and are far from exchange equilibrium with the

563 geothermal fluid (large measured $\Delta_{\text {fsp-w }}$ ). However given the low temperatures for these three

564 samples, equilibrium $\Delta_{\text {fsp-w }}$ values are even larger. The second exception where measured $\Delta_{\text {fsp-w }}$

565 values are less than equilibrium $\Delta_{\text {fsp-w }}$ values are the most ${ }^{18} \mathrm{O} /{ }^{16} \mathrm{O}$ depleted feldspars from $33 \mathrm{~A}-7$

566 and 68-6. These two samples are discussed in the following section.

$567 \quad$ Figure 11a also shows that in general, the lower the $\delta^{18} \mathrm{O}$ value of the feldspar, the closer

568 the feldspar approaches exchange equilibrium with the geothermal reservoir fluid (e.g., measured

$569 \Delta_{\text {fsp-w }}$ approaches equilibrium $\left.\Delta_{\text {fsp-w }}\right)$. This positive correlation indicates that the feldspar moves

570 progressively toward oxygen isotope exchange equilibrium with the reservoir fluid as the extent

571 of fluid-rock interaction increases (as indicated by progressively greater ${ }^{18} \mathrm{O} /{ }^{16} \mathrm{O}$ depletion in the 

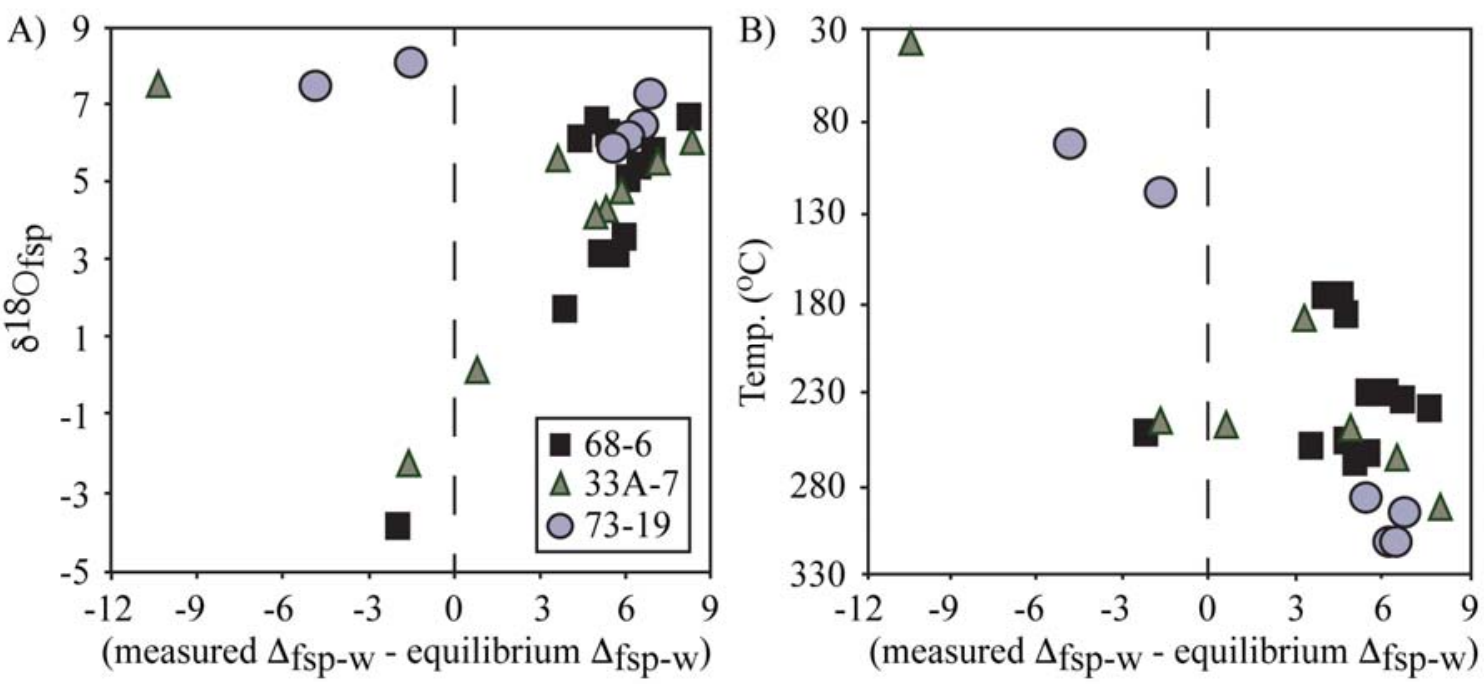

Figure 11: A) The difference between measured $\Delta_{\text {fsp-w }}$ and equilibrium $\Delta_{\text {fsp-w }}$ plotted against the measured $\delta^{18} \mathrm{O}$ value of each feldspar separate. B) The difference between measured $\Delta_{\text {fsp-w }}$ and equilibrium $\Delta_{\text {fsp-w }}$ plotted against measured temperature (pre-production) for the feldspar sample. Equilibrium $\Delta_{\text {fsp-w }}$ is calculated at pre-production temperatures. The dashed line represents equilibrium (measured $\Delta_{\text {fsp-w }}=$ equilibrium $\Delta_{\text {fsp-w }}$ ) between analyzed feldspar and the preproduction reservoir fluid. Feldspars plotting to right of the dashed line have incompletely exchanged oxygen isotopes with the reservoir fluid.

feldspar and higher calculated W/R ratio). Experimental studies and theoretical considerations indicate that the rate of oxygen isotope exchange accompanying the types of surface reactions responsible for producing the hydrothermal alteration minerals observed at Coso Hot Springs increases with increasing surface area (Cole and Chakraborty, 2001). The positive correlation between the progressive ${ }^{18} \mathrm{O} /{ }^{16} \mathrm{O}$ depletion in the feldspar and the increasing approach to oxygen

586 isotopic exchange equilibrium (measured $\Delta_{\text {fsp-w }}$ approaches equilibrium $\Delta_{\text {fsp-w }}$ ) observed for most

587 of the feldspar samples suggests that increases in permeability of the reservoir host rock produce

588 an increase in surface area of the host rock exposed to geothermal fluid, promoting fluid-rock

589 interaction and isotopic exchange.

$590 \quad$ Rates of isotopic exchange accompanying hydrothermal alteration also increase

591 dramatically with increasing temperature (Cole and Chakraborty, 2001). However, there is no 
592 systematic correlation of temperature with the extent of exchange equilibrium between the

593 feldspar and reservoir fluid (figure 11b). The excess of measured $\Delta_{\text {fsp-w }}$ compared to equilibrium

$594 \Delta_{\text {fsp-w }}$ value for feldspar samples from $68-6$ is clearly independent of temperature from $180^{\circ} \mathrm{C}$ to

$595265^{\circ} \mathrm{C}$; for example, across the temperature range of $225-265^{\circ} \mathrm{C}$ the difference between the

596 measured $\Delta_{\text {fsp-w }}$ and equilibrium $\Delta_{\text {fsp-w }}$ decreases from 6.3 to -2.0 and then increases to 5.9. A

597 similar situation holds for samples from $33 \mathrm{~A}-7$ over the temperature interval from $190{ }^{\circ} \mathrm{C}$ to 250

$598{ }^{\circ} \mathrm{C}$; the difference between measured and equilibrium $\Delta_{\text {fsp-w }}$ values changes from 3.6 down to -

$599 \quad 1.7$ and then abruptly increases to 5 .

600

Thermal and oxygen isotope evolution of geothermal fluids in the Coso system

Measured $\delta^{18} \mathrm{O}$ values of the feldspars are plotted as a function of the pre-production

602 temperature in figure 12. Curved lines define the calculated $\delta^{18} \mathrm{O}$ values of feldspar in

603 equilibrium with a range of $\delta^{18} \mathrm{O}$ values of water, including the pre-production reservoir fluids

604 (solid line). It is apparent that the analyzed feldspars from higher temperatures $\left(>200^{\circ} \mathrm{C}\right)$ in $73-19$

605 plot well above the equilibrium curve for the reservoir fluid, and are far from exchange

606 equilibrium with the reservoir fluid. These feldspars have experienced limited oxygen isotope

607 exchange, either from kinetic barriers to isotopic exchange (from lower temperatures in the

608 past?) or limited physical contact between the reservoir fluid and rock owing to lower

609 permeability, or both.

610 Many of the feldspar samples from 68-6 and 33A-7 have experienced greater ${ }^{18} \mathrm{O} /{ }^{16} \mathrm{O}$

611 depletion and therefore more extensive oxygen isotope exchange, but have not equilibrated with

612 the reservoir fluid (Fig. 12). In contrast, the two feldspars from 33A-7 and 68-6 with the lowest

$613 \delta^{18} \mathrm{O}$ values plot below the equilibrium curve for the reservoir fluid. For these two feldspar

614 samples, measured $\Delta_{\text {fsp-w }}$ values are less than equilibrium $\Delta_{\text {fsp-w }}$ values by -1.66 (33A-7_2471.9 
Temperature $\left({ }^{\circ} \mathrm{C}\right)$
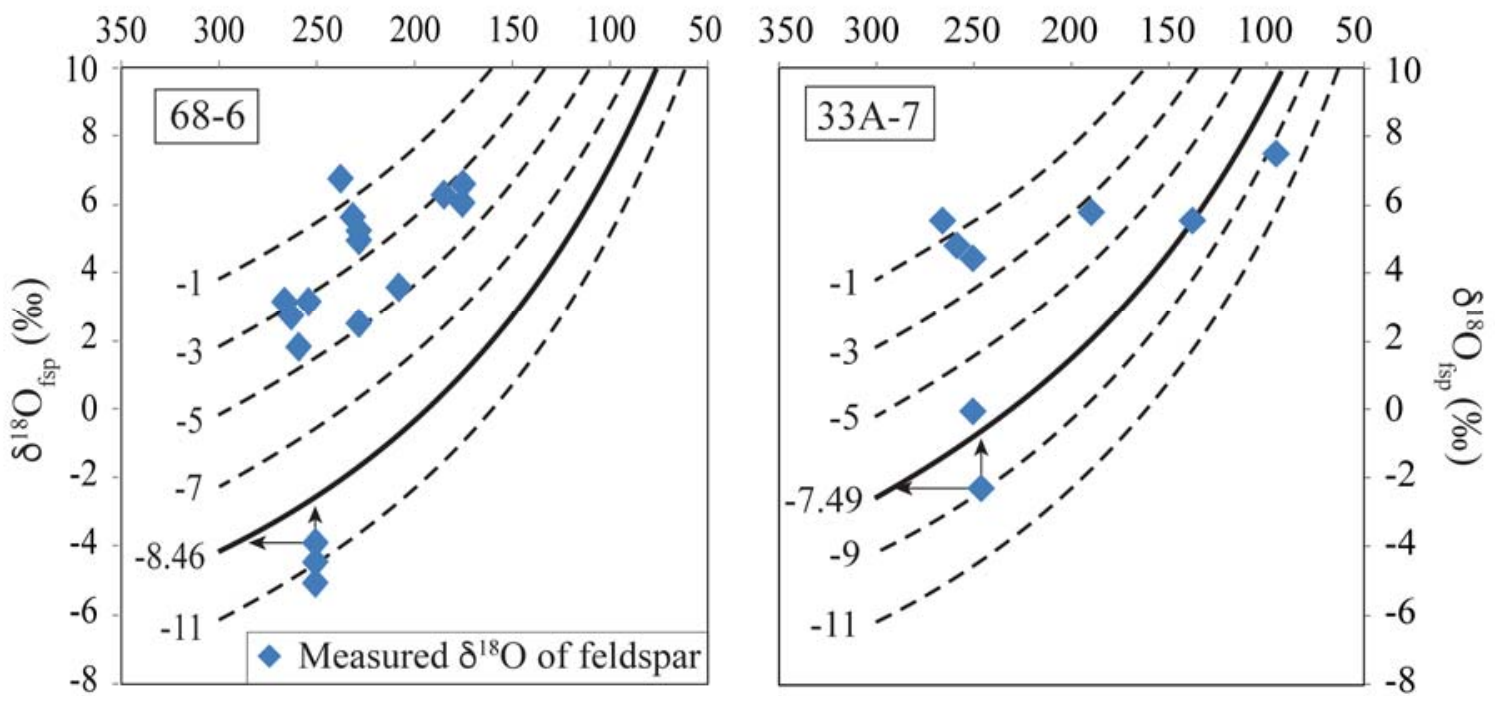

Temperature $\left({ }^{\circ} \mathrm{C}\right)$

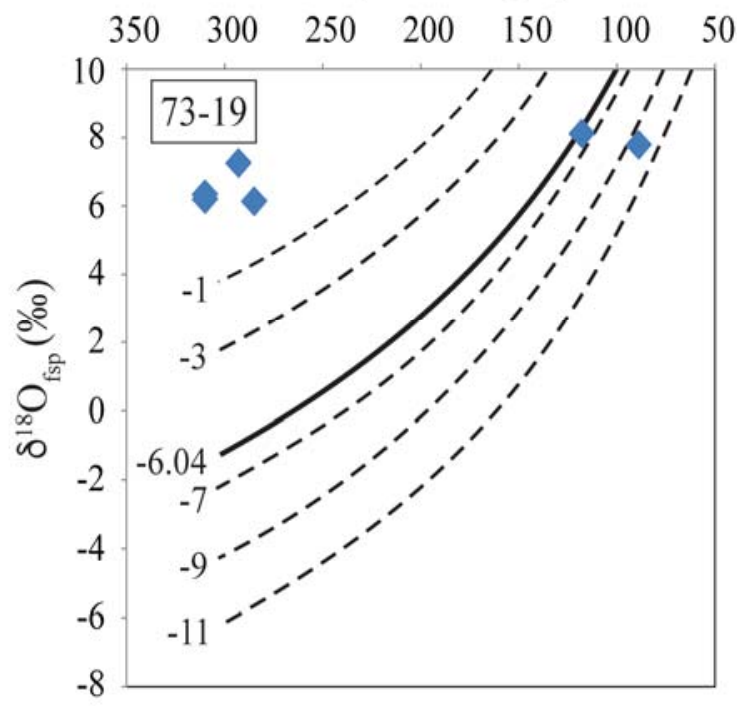

615

616

617

618

619

620

621

622
Figure 12: Measured $\delta^{18} \mathrm{O}$ values of feldspars plotted as a function of pre-production temperatures. Curved lines define the calculated $\delta^{18} \mathrm{O}$ values of feldspar in exchange equilibrium with a range of $\delta^{18} \mathrm{O}$ values of water (values specified next to each curve), including the preproduction reservoir fluids in these wells (solid line), as a function of temperature. Arrows indicate changes in temperature or $\delta^{18} \mathrm{O}$ of reservoir fluid needed for the most ${ }^{18} \mathrm{O} /{ }^{16} \mathrm{O}$-depleted feldspar in 68-6 and 33A-7 to achieve oxygen isotope exchange equilibrium with the geothermal reservoir fluids. 
$624 \mathrm{~m})$ and -1.99 (68-6_2941.3 m) (Fig. 11a). At pre-production temperatures, incomplete isotopic

625 exchange would produce measured $\Delta_{\text {fsp-w }}$ values greater than the equilibrium $\Delta_{\text {fsp-w }}$ values.

626 Therefore these discrepancies cannot result from incomplete oxygen isotope exchange between

627 the geothermal fluid and the reservoir rocks, because of either slow isotopic exchange kinetics or

628 lack of physical contact between fluid and feldspar crystals. Measured $\Delta_{\text {fsp-w }}$ less than

629 equilibrium $\Delta$ fsp-w requires that the isotopic exchange took place either at higher temperatures

630 and/or with a reservoir fluid of lower $\delta^{18} \mathrm{O}$ value. Figure 12 shows that temperatures would need

631 to increase by $55^{\circ} \mathrm{C}$ (to $307^{\circ} \mathrm{C}$ ) and $42{ }^{\circ} \mathrm{C}$ (to $288^{\circ} \mathrm{C}$ ) in 68-6 and $33 \mathrm{~A}-7$, respectively, for the

632 most ${ }^{18} \mathrm{O} /{ }^{16} \mathrm{O}$-depleted feldspars from each well to be in exchange equilibrium with the reservoir

633 fluid. Alternatively, the $\delta^{18} \mathrm{O}$ values of geothermal fluids would need to decrease by $1.98 \%$ and

$6341.66 \%$ in 68-6 and 33A-7, respectively (tables 3,4; fig. 12). A lower $\delta^{18} \mathrm{O}$ value of the reservoir

635 fluid in the past implies a decrease in the initial $\delta^{18} \mathrm{O}$ value of the meteoric water source, and/or

636 an increase in the W/R ratio (and permeability) for these sections of geothermal system.

637

638

639

640

641

642

643

644 following:

645 - Clay mineral distribution in three wells along the West Flank is not always closely 646

\section{CONCLUSIONS}

The patterns and extent of ${ }^{18} \mathrm{O} /{ }^{16} \mathrm{O}$ depletions measured in the reservoir rocks of the Coso Hot Springs geothermal system, combined with clay mineral alteration patterns, record significantly varying degrees of fluid-rock interactions. These patterns provide insights into the role of fracture-controlled permeability in this geothermal system. Our results indicate the correlated with the distribution expected from preproduction temperatures. There is, 
however, a general correlation between greater and more widespread ${ }^{18} \mathrm{O} /{ }^{16} \mathrm{O}$ depletion in the northern part of the West Flank with a thinner smectite zone and disappearance of the illite/smectite zone. This correlation suggests that clay mineral distributions in the Coso Hot Springs field is a function of both the extent of fluid-rock interaction and temperature.

- Whole-rock and feldspar $\delta^{18} \mathrm{O}$ analyses define patterns of ${ }^{18} \mathrm{O} /{ }^{16} \mathrm{O}$ depletion in the West Flank distinct from those expected from regional metamorphism. These oxygen isotope analyses show that the reservoir rocks have experienced a wide range of ${ }^{18} \mathrm{O} /{ }^{16} \mathrm{O}$ depletion, from negligible depletion below primary $\delta^{18} \mathrm{O}$ values of $+7.5 \%$ to $\delta^{18} \mathrm{O}$ values as low as $-6 \%$ for feldspar. This large range indicates that the reservoir rocks have experienced significant variation in the extent of fluid-rock interaction.

- Detailed $\delta^{18} \mathrm{O}$ measurements of whole rock and feldspar samples from three wells along the West Flank identify a limited number of localized intervals of extensive ${ }^{18} \mathrm{O} /{ }^{16} \mathrm{O}$ depletion where the host rocks have interacted and exchanged isotopically with significant quantities of geothermal fluid (high calculated W/R ratios). The local zones of maximum ${ }^{18} \mathrm{O} /{ }^{16} \mathrm{O}$ depletion in each well correspond closely with the depths of the current production zones (intervals of high permeability). Rocks between these intervals have experienced much less exchange. These patterns likely reflect that permeability in the reservoir host rock is fracture-controlled.

- Most analyzed feldspars have $\delta^{18} \mathrm{O}$ values too high to have completely exchanged with the reservoir fluid. The analyses also show that in general, the lower the $\delta^{18} \mathrm{O}$ value of the feldspar (the greater the extent of fluid-rock interaction), the closer the feldspar approaches isotope exchange equilibrium with the geothermal fluid. This positive 
correlation suggests that fracture-induced increases in permeability of the reservoir host rock increase mineral/grain surface area exposed to geothermal fluids, promoting fluidrock interaction and isotopic exchange.

673 - There is no systematic correlation of temperature with either the extent of ${ }^{18} \mathrm{O} /{ }^{16} \mathrm{O}$

674 depletion or the extent of exchange equilibrium between the feldspar and reservoir fluid

675 in the West Flank. This is particularly the case for 73-19, where rock host has experienced only moderate and highly localized ${ }^{18} \mathrm{O} /{ }^{16} \mathrm{O}$ depletion despite having the highest measured temperatures in the three wells. Thus in the West Flank at Coso Hot Springs (a crystalline-rock-hosted geothermal system), permeability is as, or more important than temperature in driving fluid-rock interaction and isotopic exchange.

- The three feldspar samples with the lowest $\delta^{18} \mathrm{O}$ values are all from current production zones in the reservoir. These feldspars are highly depleted in ${ }^{18} \mathrm{O} /{ }^{16} \mathrm{O}$ and therefore have experienced extensive fluid-rock interaction and isotopic exchange. However, two of these feldspar separates have measured $\Delta_{\text {fsp-w }}<$ equilibrium $\Delta_{\text {fsp-w }}$ which requires that they have equilibrated with the pre-production reservoir fluid at higher temperature, or with a lower $\delta^{18} \mathrm{O}$ reservoir fluid. These discrepancies suggest that the West Flank of the Coso geothermal system was hotter and/or characterized by higher permeability (higher $\mathrm{W} / \mathrm{R}$ ratio) during fluid-rock exchange in the past.

\section{$\underline{\text { Acknowledgements }}$}

A U.S. Department of Energy (DOE) grant to Moore is gratefully acknowledged. Terra-Gen has provided access to well cuttings, and a variety of geological, geochemical and geophysical data on the Coso Hot Springs geothermal system. 
Adams, M.C., Moore, J.N., Bjornstad, S., and Norman, D.I., (2000) Geologic History of the

Cole, D.R., Ohmoto, H. and Jacobs, G.K. (1992) Isotopic exchange in mineral-fluid systems: III. Rates and mechanisms of oxygen isotope exchange in the system granite- $\mathrm{H}_{2} \mathrm{O} \pm \mathrm{NaCl} \pm \mathrm{KCl}$ at hydrothermal conditions: Geochimica et Cosmochimica Acta, v. 56, p. 445-466

Cole, D.R. and Chakraborty, S. (2001) Rates and mechanisms of isotopic exchange in $\underline{\text { Stable }}$ Isotope Geochemistry, J.W. Valley and D.R. Cole (eds), Reviews in Mineralogy and Geochemistry, v. 43, 83-223

Bartley, J.M., Glazner, A.F., Coleman, D.S., Kylander-Clark, A., Mapes, R., and Friedrich, A.M. (2007) Large Laramide dextral offset across Owens Valley, California, and its possible relation to tectonic unroofing of the southern Sierra Nevada: The Geological Society of America Special Paper, v. 434, p. 129-148

Baumgartner, L.P., and Rumble, D., III, (1988) Transport of stable isotopes-I. development of continuum theory for stable isotope transport: Contributions to Mineralogy and Petrology, v. 98 , p. $417-430$

Baumgartner, L.P., and Valley, J.W. (2001) Stable isotope transport and contact metamorphic fluid flow in Stable Isotope Geochemistry, J.W. Valley and D.R. Cole (eds), Reviews in Mineralogy and Geochemistry, v. 43, p. 415-461

Bishop, B. and Bird, D. (1987) Variation in sericite compositions from fracture zones within the Coso Hot Springs geothermal system: Geochimica et Cosmochimica Acta, v. 51, p. 12451256

Bowman, J.R., and Willett, S.D. (1991) Spatial patterns of oxygen isotope exchange during onedimensional fluid infiltration: Geophysical Research Letters, v. 18, p. 971-974

Bowman, J.R., Willett S.D., Cook, S.J. (1994) Oxygen isotopic transport and exchange during fluid flow: one-dimensional models and applications: American Journal of Science, v. 294, p. $1-55$

Browne, P. (1978) Hydrothermal alteration in active geothermal fields: A geochemical review: Annual reviews in Earth and Planetary Science, v. 6, p. 229-250

Browne, P. (1984), Lectures on geothermal geology and petrology: UNU Geothermal Training Programme, Iceland, Report 1984-2 
Cook, S. J., Bowman, J. R., and Forster, C. B. (1997) Contact metamorphism surrounding the Alta Stock: Finite element model simulation of heat- and ${ }^{18} \mathrm{O} /{ }^{16} \mathrm{O}$ mass-transport during prograde metamorphism: American Journal of Science, v. 297, p. 1-55

Criss, R.E. and Taylor, H.P. Jr. (1983) An ${ }^{18} \mathrm{O} /{ }^{16} \mathrm{O}$ and D/H study of Tertiary hydrothermal system in the southern half of the Idaho batholith: GSA Bulletin, v. 94, p. 640-663

Criss, R.E. and Taylor, H.P. Jr. (1986) Meteoric-hydrothermal systems" in Stable Isotopes in High Temperature Geological Processes, J.W. Valley, H.P. Taylor, Jr. and J.R. O’Neil (eds): Reviews in Mineralogy v. 16, p. 373-422

Duffield, W.A., Bacon, C.R., and Dalrymple, G.B. (1980) Late Cenozoic volcanism, geochronology, and structure of the Coso Range, Inyo County, California: Journal of Geophysical Research, v. 85, p. 2381-2404

Etzel, T.M. (2015) Oxygen isotope composition and tourmaline mineral chemistry of the Coso and Darajat geothermal systems: Masters thesis, University of Utah

Fournier, R.O, Thompson, J.M., and Austin, C.F. (1980) Interpretation of chemical analyses of waters collected from two geothermal wells at Coso, California: Journal of Geophysical Research, v. 85, p. 2405-2410

Henley, R.W. and Ellis, A.J. (1983) Geothermal systems ancient and modern: a geochemical review: Earth Science Reviews, v. 19, p. 1-50

Hulen, J.B., 1978, Geology and alteration of the Coso Geothermal Area, Inyo County, California: University of Utah Research Institute Report DOE/ID/28392-4, p. 1-28

Kaven, J.O., Hickman, S.H., and Davatzes, N.C. (2012) Using micro-seismicity and seismic velocities to map subsurface geologic and hydrologic structure within the Coso geothermal field, California: Proceedings, $37^{\text {th }}$ workshop on Geothermal Reservoir Engineering, Stanford, CA, p. 1085-1092

Kovac, K.M., Moore, J., McCulloch, D.E. (2004) Geology and mineral paragenesis study within the Coso-EGS project: Proceedings, $29^{\text {th }}$ workshop on Geothermal Reservoir Engineering, Stanford, CA, p. 262-267

Kovac, K.M., Moore, J.N., and Lutz, S.J. (2005) Geologic Framework of the East Flank, Coso Geothermal Field: Implications for EGS Development: Proceedings, 30 ${ }^{\text {th }}$ Workshop on Geothermal Reservoir Engineering, p. 486-492

Kurliovitch, L., Norman, D., Heizler, M., Moore, J., and McCulloch, J. (2003), ${ }^{40} \mathrm{Ar} /{ }^{39} \mathrm{Ar}$ Thermal History of the Coso Geothermal Field: Proceedings, $28^{\text {th }}$ Workshop on Geothermal Reservoir Engineering, Stanford, CA, p. 110-116 
Lackey, J.S., Valley, J.W., Chen, J.H., and Stockli, D.F. (2008) Dynamic magma systems, crustal recycling, and alteration in the central Sierra Nevada Batholith: the oxygen isotope record: Journal of Petrology, v. 49, p. 1397-1426

Lutz, S.J., Moore J.N., and Copp J.F. (1996) Integrated mineralogical and fluid inclusion study of the Coso geothermal system, California: Proceedings, $21^{\text {st }}$ workshop on geothermal reservoir engineering, Stanford, CA, p. 187-194

Lutz, S.J., and Moore, J.N. (1997). Petrographic and X-ray diffraction study of 130 cuttings samples from six wells in the Coso geothermal area, California, unpublished CalEnergy Corporation Report

Manley, C.R., and Bacon, C.R. (2000) Rhyolite Thermobarometry and the Shallowing of the Magma Reservoir, Coso Volcanic Field, California: Journal of Petrology v. 41, p. 149-174

Masi, U., O’Neil, J.R., and Kistler, R.W. (1981) Stable isotope systematics in Mesozoic granites of central and northern California and southwestern Oregon: Contributions to Mineralogy and Petrology, v. 76, p. 116-126

Monastero, F.C., Katzenstein, A.M., Miller, J.S., Unruh, J.R., Adams, M.C., Richards-Dinger, K. (2005) The Coso geothermal field: a nascent metamorphic core complex: Geologic Society of America Bulletin v. 117, p. 1534-1553

Moore, J.N., Adams, M.C., Bishop-Gollan, B., Copp, J.F., and Hirtz, P. (1990) Geochemical structure of the Coso geothermal system, California: American Association of Petroleum Geologists Guidebook, Coso Field Trip, AAPG EMD \#1, Moore J.L. and Erskine, M., eds., p.25-39

O’Neil, J.R., and Taylor, H.P. Jr. (1967) The oxygen isotope and cation exchange chemistry of feldspars: The American Mineralogist, v. 52, p. 1414-1437

Person, M. A., Sabin, A. E., Unruh, J. R., Gable, C. W., Zyvoloski, G. A., and Monastero, F. C. (2006) Isotope transport and exchange within the Coso geothermal system: Proceedings, $30^{\text {th }}$ Workshop on Geothermal Reservoir Engineering, v. 30, p. 159-164

Pope, E.C., Bird, D.K., Arnorsson, S., and Giroud, N. (2016) Hydrogeology of the Krafla geothermal system, northeast Iceland: Geofluids, v. 16, p. 175-197

Reasenberg, P., Ellsworth, W., and Walter, A. (1980) Teleseismic evidence for a low-velocity body under the Coso Geothermal Field: Journal of Geophysical Research, v. 85, p. 24712483

Reyes, A. G. (1990) Petrology of Philippines geothermal systems and the application of alteration mineralogy to their assessment: Journal of Volcanology and Geothermal Resources, v. 43, p. 279-309 
Spicuzza, M.J., Valley, J.W., and, McConnell V.S. (1998) Oxygen isotope analysis of whole rock via laser fluorination: an air-lock approach: GSA Abstracts with Programs, v. 30, p. 80

Steiner, A. (1968) Clay Minerals in hydrothermally altered rocks in Wairakei, New Zealand. Clays: Clay Mineralogy, v. 16, p. 193-213

Taylor, H.P., Jr. (1971) Oxygen isotope evidence for large-scale interaction between meteoric ground waters and Tertiary granodiorite intrusion, western Cascade Range, Oregon: Journal of Geophysical Research, v. 76, p. 7855-7874

Taylor, H. P., Jr. and Forester, R.W. (1979) An oxygen and hydrogen isotope study of the Skaergaard intrusion and its country rocks: A description of a 55-M.Y. old fossil hydrothermal system: Journal of Petrology, v. 20, p. 355-419

Truesdell, A.H. (1984) Stable isotopes in hydrothermal systems in Fluid-mineral Equilibria in Hydrothermal Systems, J.M Robertson (ed): Reviews in Economic Geology, v. 1, p. 129-141

Valley, J.W. and Graham, C.M.,1996, Ion microprobe analysis of oxygen isotope ratios in quartz from Skye granite: healed micro-cracks, fluid flow, and hydro-thermal exchange. Contributions Mineralogy Petrology, vol. 124, 3/4, p. 225-234

Valley, J.W. and Kita, N.T., 2009, In situ Oxygen Isotope Geochemistry by Ion Microprobe, In: Fayek, M. (ed) MAC Short Course: Secondary Ion Mass Spectrometry in the Earth Sciences, vol. 41, p. 19-63

Valley, J. W., Kitchen, N., Kohn, M. J., Niendorf, C. R., and Spicuzza, M. J. (1995) UWG-2, A garnet standard for oxygen isotope ratio-Strategies for high precision and accuracy with laser heating: Geochimica et Cosmochimica Acta, v. 59, p. 5223-5231

Williams, A. E. and McKibben, M. A. (1990) Isotopic and chemical constraints on reservoir fluids from the Coso geothermal field, California: Proceedings, $14^{\text {th }}$ Workshop on Geothermal Reservoir Engineering, Stanford, CA, p. 1545-1552

Wilson, C.K., Jones, C.H., and Gilbert H.J., (2003) A single-chamber silicic magma system inferred from shear-wave discontinuities of the crust and uppermost mantle, Coso geothermal area, California, Journal of Geophysical Research, v. 108, B5 